Notre Dame Law School

NDLScholarship

\title{
What Is Caesar's, What Is God's: Fundamental Public Policy for Churches
}

Lloyd Histoshi Mayer

Notre Dame Law School, Imayer@nd.edu

Zachary B. Pohlman

Notre Dame Law School, zbpohlman@gmail.com

Follow this and additional works at: https://scholarship.law.nd.edu/law_faculty_scholarship

Part of the First Amendment Commons, Nonprofit Organizations Law Commons, Religion Law Commons, and the Tax Law Commons

\section{Recommended Citation}

Lloyd H. Mayer \& Zachary B. Pohlman, What Is Caesar's, What Is God's: Fundamental Public Policy for Churches, 44 Harv. J. L. \& Pub. Pol'y (2021) Forthcoming.

Available at: https://scholarship.law.nd.edu/law_faculty_scholarship/1419

This Article is brought to you for free and open access by the Publications at NDLScholarship. It has been accepted for inclusion in Journal Articles by an authorized administrator of NDLScholarship. For more information, please contactlawdr@nd.edu. 


\title{
WHAT Is CAESAR'S, WHAT Is GOD'S: Fundamental Public Policy For Churches
}

\author{
LLOYD HITOSHI MAYER* \& ZACHARY B. POHLMAN**
}

\begin{abstract}
Bob Jones University v. United States is a highly debated Supreme Court decision, both regarding whether it was correct and what exactly it stands for, and a rarely applied one. Its recognition of a "fundamental public policy doctrine" that could cause an otherwise tax-exempt organization to lose its favorable federal tax status remains highly controversial, although the Court has shown no inclination to revisit the case, and Congress has shown no desire to change the underlying statutes to alter the case's result. That lack of action may be in part because the IRS applies the decision in relatively rare and narrow circumstances.

The mention of the decision during oral argument in Obergefell v. Hodges raised the specter of more vigorous and broader application of the doctrine, however. It renewed debate about what public policies other than avoiding racial discrimination in education might qualify as fundamental and also whether and to what extent the doctrine should apply to churches, as opposed to the religious schools involved in the original case. The IRS has taken the position that churches are no different than any other taxexempt organizations in this context, although it has only denied or revoked the tax-exempt status of a handful of churches based on this doctrine.

* Professor, Notre Dame Law School.

** J.D. candidate, Notre Dame Law School, 2021. The authors are very grateful for helpful comments on earlier drafts from Stephanie Barclay, Boyd Black, Mark E. Chopko, Richard W. Garnett, and participants in the NYU School of Law National Center on Philanthropy and the Law Annual Conference and the Notre Dame Faculty Colloquium. Copyright (C) 2021 by Lloyd Hitoshi Mayer and Zachary B. Pohlman.
\end{abstract}


The emergence of the Bob Jones University decision in the Obergefell oral argument renders consideration of these issues particularly timely, especially in light of developments over the past several decades both with respect to the legal status of churches and what arguably could be considered fundamental policy. This Article therefore explores whether there are emerging conflicts between a significant number of churches and what could be considered fundamental public policy, not only with respect to sexual orientation discrimination but also with respect to sex discrimination, sanctuary churches, and other areas. Finding that there are several current or likely future such conflicts, it then explores whether there are philosophical and legal grounds for treating churches differently from other tax-exempt organizations for purposes of applying the contrary-tofundamental-public-policy doctrine and the related illegality doctrine. Drawing on both the longstanding concept of "sphere sovereignty" and emerging work in the area of First Amendment institutions, the Article concludes that churches should not be subject to the former doctrine, but that they still should be subject to loss of their tax benefits if they engage in or encourage significant criminal activity. The Article then concludes by applying this conclusion to the identified areas of current or likely future conflict to demonstrate how the IRS and the courts should apply the Bob Jones University decision to churches. 


\section{TABLE OF CONTENTS}

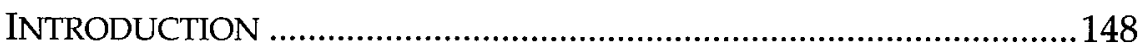

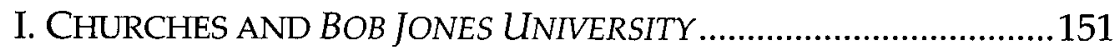

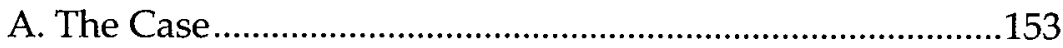

B. Subsequent Rulings and IRS Actions Involving

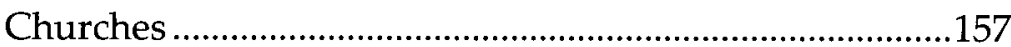

II. CHURCHES AND FUNDAMENTAL PUBLIC POLICY ......................160

A. Why the Uniqueness of Racial Discrimination in Education Should Not Control .............................................................161

B. Discrimination in Employment, Services, and

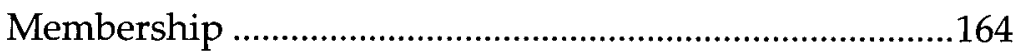

C. Protecting and Serving Undocumented Immigrants ........175

D. Other Possible Conflicts .......................................................177

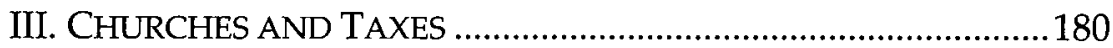

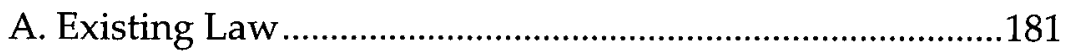

B. Constitutional Reasons for Tax Benefits ...............................184

C. Policy Reasons for Tax Benefits ............................................189

IV. WHY THE INSTITUTIONAL CONTEXT SHOULD CONTROL.........195

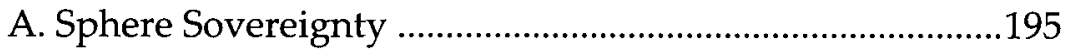

B. First Amendment Institutions ................................................214

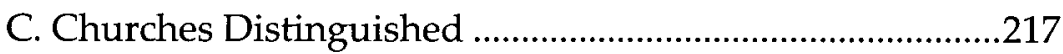

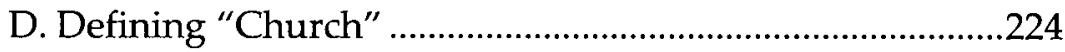

V. REVISITING CHURCHES AND BOB JONES UNIVERSITY ................226

A. Current Significant Conflicts ...................................................227

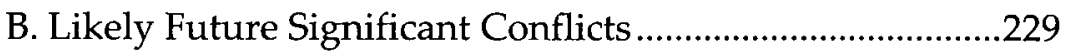

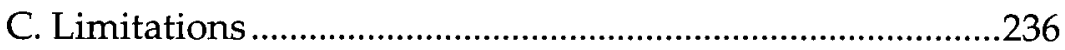

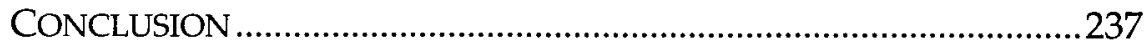




\section{INTRODUCTION}

"Tell us then, what is your opinion? Is it right to pay the imperial tax to Caesar or not?" But Jesus, knowing their evil intent, said, "You hypocrites, why are you trying to trap me? Show me the coin used for paying the tax." They brought him a denarius, and he asked them, "Whose image is this? And whose inscription?" "Caesar's," they replied. Then he said to them, "So give back to Caesar what is Caesar's, and to God what is God's."1

The relationship of churches and governments has a long and fraught history, including with respect to taxes. ${ }^{2}$ Policymakers, church leaders, and various commentators have put forward numerous reasons both for and against preferential tax treatment for some or all churches. ${ }^{3}$ And when governments provide such preferential tax treatment, as they often do, the issue then arises of what - if any - conditions can and should apply to such treatment.

More than thirty-five years ago the United States Supreme Court's decision in Bob Jones University $v$. United States ${ }^{4}$ sent shock waves through religious congregations even though the case itself involved religious schools and not churches. ${ }^{5}$ This was because the case suggested that any organization, even a church, that was exempt from federal income tax as a "charity" and so also eligible to receive tax deductible charitable contributions, could lose those benefits if found to have an activity or purpose that was illegal or otherwise "contrary to a fundamental public policy."6 The vagueness of the latter phrase, combined with the specter of the Internal

1. Matthew 22:17-21 (New International Version).

2. For purposes of this Article, "churches" refers to house of worship of all types, including synagogues, mosques, and temples. For a discussion of more specific legal definitions, see infra Part IV.D.

3. See infra Parts III.B. and III.C.

4. 461 U.S. 574 (1983).

5. Id. at 574 .

6. Id. at 591-92. 
Revenue Service making determinations regarding what constitutes fundamental public policy, only heightened the fear that the case could usher in new and intrusive IRS supervision of churches.

However, reality did not come to reflect this fear. The IRS has sought to strip tax benefits from churches based on Bob Jones University or the doctrine that it established only five times: once related to one of the parties in Bob Jones University, three times for churches involved in illegal criminal activity, and once for an unapologetically racist church where the exact reasons for the revocation are unclear. $^{8}$ Indeed, the IRS has shown little interest in expanding the application of this case beyond situations involving either racial discrimination or significant illegal activity. ${ }^{9}$

Bob Jones University nevertheless remains good law, and the following exchange during oral argument in the Obergefell v. Hodges ${ }^{10}$ same-sex marriage case reawakened the concerns of many religious organizations and leaders:

JUSTICE ALITO: Well, in the Bob Jones case, the Court held that a college was not entitled to tax-exempt status if it opposed interracial marriage or interracial dating. So would the same apply to a university or a college if it opposed same-sex marriage?

[SOLICITOR] GENERAL VERRILLI: You know, I-I don't think I can answer that question without knowing more specifics, but it's certainly going to be an issue. I-I don't deny that. I don't deny that, Justice Alito. It is - it is going to be an issue. ${ }^{11}$

7. See, e.g., William A. Drennan, Bob Jones University v. United States: For Whom Will the Bell Toll?, 29 ST. LouIS U. L.J. 561, 588-93 (1985); Joe W. Miller, Note, Applying a Public Benefit Requirement to Tax-Exempt Organizations, 49 MO. L. REV. 353, 366, 368 (1984).

8. See infra Part I.B.

9. See infra note 33 and accompanying text.

10. 576 U.S. 644 (2015).

11. Transcript of Oral Argument at 38, Obergefell v. Hodges, 576 U.S. 644 (2015) (No. 14-556). 
This point was not lost on the dissenters in that case, who highlighted this possibility. ${ }^{12}$ And it does not take much imagination to apply Solicitor General Verrilli's response to churches, many of which have strong positions opposing same-sex marriage. ${ }^{13}$

So to what extent does Bob Jones University, combined with changing views of what constitutes fundamental public policy, actually threaten the tax benefits enjoyed by churches? Part I of this Article considers what the Court actually decided in that case, including its (very limited) discussion of how its decision might apply to churches. Part I also reviews the few subsequent applications of that decision to churches by the IRS and the courts. Part II then identifies several existing and likely future conflicts between churches and fundamental public policy that the IRS and courts have yet to address. The remainder of this Article then explores how the IRS and courts should resolve these new conflicts. Part III begins this exploration by considering the extent to which churches enjoy preferential tax treatment in the United States, the reasons for such treatment, and the constitutional ramifications of that treatment, all of which could affect the application of Bob Jones University to churches. Part IV then explores the philosophical and legal basis for treating churches differently for tax purposes generally and with respect to application of Bob Jones University specifically. Finally, Part V pulls these strands together to provide a more complete answer to how Bob Jones University should apply to churches. While many other scholars have addressed the issues covered in the first four Parts, none have pulled together all of these various lines of thought to comprehensively consider how Bob Jones University should apply to churches in the twenty-first century.

12. Obergefell, 576 U.S. at 711 (Roberts, C.J., dissenting); see also Laurie Goodstein \& Adam Liptak, Schools Fear Gay Marriage Ruling Could End Tax Exemptions, N.Y. TIMES, June 24, 2015, at A13.

13. See, e.g., Benjy Sarlin, O'Rourke says churches against gay marriage should lose tax benefits, draws backlash, NBC NEwS (Oct. 11, 2019), https://www.nbcnews.com/politics/2020-election/o-rourke-says-churches-against-gay-marriage-should-lose-taxn1065186 [https://perma.cc/U9PX-JF22]. 
Our conclusion is that churches should be at risk of losing their federal tax benefits only if they engage in significant criminal activities and not if their activities or purposes are only contrary to fundamental public policy. The reason for this limitation on the application of Bob Jones University is that the tax benefits for churches are based not only on a quid pro quo theory - that the societal benefits they provide are sufficient to justify those tax benefits - but also on a "soft sovereignty" theory that grants them significant autonomy from the government, including with respect to taxes, in recognition of their distinct role in society. The legal bases for this soft sovereignty approach are the First Amendment's Religion Clauses and the need for governments generally to avoid both substantially burdening religious exercise and undue entanglement with religious institutions. However, given both the continued viability of $B o b$ Jones University and other considerations discussed below, this limited application applies only to churches and not to other religious organizations, such as the religious schools in the Bob Jones University case. And since churches are not co-equal sovereigns with the government and so are not above the law, in the rare instances where it is conclusively shown that a church is engaging in substantial criminal activities that demonstrate a significant criminal purpose, the church should lose the tax benefits it otherwise would enjoy. In other words, this approach provides a demarcation between what in this context belongs to Caesar and what does not that appropriately balances the legal rights of churches with the legal authority of the state.

\section{CHURCHES AND BOB JONES UNIVERSITY}

Numerous commentators have described and analyzed the background, reasoning, and aftermath of Bob Jones University in great detail. ${ }^{14}$ The purpose of this Article is not to cover that well-trodden 
ground in detail or the many critiques of the Court's reasoning. Rather, for purposes of this Article we will accept the case as binding-a realistic assumption, given that the Supreme Court has shown no inclination to revisit it and Congress has shown no interest in revising the applicable statutes to modify or overrule it. We will instead focus on the points most salient to the case's potential application to churches, including the few actual such applications by the IRS and the courts in the wake of that decision. One important ramification of this assumption relates to the case's application to organizations that are religious in the sense that their missions flow from sincerely held religious beliefs but are not generally considered churches, including the schools involved in the case. Since the Court squarely rejected a First Amendment free exercise of religion argument that such organizations should not be subject to the fundamental public policy doctrine as applied in the case, ${ }^{15}$ we will only briefly revisit that issue here, even though our analysis arguably could extend to such organizations. ${ }^{16}$ The focus of this Article is therefore to address an issue explicitly left open by the Court in Bob Jones University - to what extent the Court's holding should apply to churches. ${ }^{17}$

lic Policy Constraints on Charitable Organizations, 3 VA. TAX REV. 291 (1984); Michael Hatfield et al., Bob Jones University: Defining Violations of Fundamental Public Policy (Nat'1 Ctr. Philanthropy \& L., Topics in Philanthropy no. 6, 2000), https://ncpl.law.nyu.edu/wp-content/uploads/pdfs/Monograph/Monograph2000BobJones.pdf [https://perma.cc/NLQ4-B8QL]; David J. Herzig \& Samuel D. Brunson, Let Prophets Be (Non)Profits, 52 WAKE FOREST L. REV. 1111 (2017); Olatunde C. Johnson, The Story of Bob Jones University v. United States: Race, Religion, and Congress' Extraordinary Acquiescence, in STATUTORY INTERPRETATION STORIES (William N. Eskridge et al. eds., 2011); see also Drennan, supra note 7, at $565 \mathrm{n} .21$ (collecting academic articles written about the case as it made its way to the Supreme Court).

15. See Bob Jones Univ. v. United States, 461 U.S. 574, 603-04 (1983).

16. See id. at 604-05; infra notes 345-349 and accompanying text. For an argument that religious freedom protections should extend to religious entities that provide services to the broader public, such as schools, see generally Thomas C. Berg, Partly Acculturated Religious Activity: A Case for Accommodating Religious Nonprofits, 91 NOTRE DAME L. REV. 1341 (2016).

17. See infra note 29 and accompanying text. 


\section{A. The Case}

Bob Jones University involved two nonprofit, religious, private schools with racially discriminatory policies that they based on religious doctrine. ${ }^{18}$ From 1975 through at least the time of the decision in 1983, Bob Jones University permitted African-Americans to enroll but had a disciplinary rule prohibiting interracial dating, interracial marriage, and advocacy of such; the University also did not admit applicants who were in an interracial marriage or were known to engage in such advocacy. ${ }^{19}$ Goldsboro Christian Schools, a K-12 institution, generally accepted only whites as students, although it had on occasion accepted children from racially mixed marriages in which one of the parents was white. ${ }^{20}$

The statutory provisions at issue were the Internal Revenue Code sections that usually provide nonprofit schools with tax exemption and the ability to receive tax deductible contributions. ${ }^{21}$ For purposes of this Article, the key legal question before the Court was whether Congress intended to include in those provisions a requirement that in order to receive these benefits, an organization had to satisfy a common-law standard the Court found applicable to charitable trusts: that they "must serve a public purpose and not be contrary to established public policy." 22 The Court generally answered this question in the affirmative, ${ }^{23}$ but left significant uncertainty regarding the exact parameters of this doctrine in at least four respects.

First, the Court subtly shifted its language from "established" public policy to "fundamental" public policy, without explaining the significance of this change. ${ }^{24}$ Second, it left unclear whether an 
organization disqualified itself from these tax benefits by acting contrary to such a public policy, having a purpose contrary to such public policy, or some combination of the two. ${ }^{25}$ The Court also left unclear what level of activity or priority of purpose would be required to result in disqualification. ${ }^{26}$ Third, it stated that such disqualification flowed both from illegality and from being contrary to such public policy, without explaining the difference between the two. ${ }^{27}$ Finally, it concluded that the First Amendment's Free Exercise Clause did not prevent disqualification because the government's interest in eradicating racial discrimination in education was compelling and disqualification was the least restrictive means to further that interest. ${ }^{28}$ However, the Court did not reach whether this holding extended to churches:

We deal here only with religious schools-not with churches or other purely religious institutions; here, the governmental interest is in denying public support to racial discrimination in education. As noted earlier, racially discriminatory schools "exer[t] a pervasive influence on the entire educational process," outweighing any public benefit that they might otherwise provide. ${ }^{29}$

It therefore left the application of its decision to churches uncertain.

25. See id. at $586-87$.

26. Compare id. at $587 \&$ n.11 (charitable "purposes"), 589 (public "purposes"), 591 \& n.18 ("purpose"), $592 \&$ n.19 ("purpose"), with id. at 592 ("activity"), 593 n.20 ("activities"), 596 n.21 ("activities"), 598 ("activities").

27. See id. at 591.

28. See id. at 604 . Despite the Court's use of compelling governmental interest and least restrictive means language characteristic of strict scrutiny analysis, the Court appears to have in fact applied a more deferential level of scrutiny, possibly because of the decision's tax context. See Lloyd Hitoshi Mayer, Politics at the Pulpit: Tax Benefits, Substantial Burdens, and Institutional Free Exercise, 89 B.U. L. REV. 1137, 1159 (2009); Elliot M. Schachner, Religion and the Public Treasury after Taxation with Representation of Washington, Mueller and Bob Jones, 1984 UTAH L. REV. 275, 305 (1984).

29. Bob Jones Univ., 461 U.S. at $604 \mathrm{n} .29$ (emphasis in original) (alteration in original) (citations omitted) (quoting Norwood v. Harrison, 413 U.S. 455, 469 (1973)). 
Many scholars have addressed these areas of uncertainty in detail. ${ }^{30}$ Here it is sufficient to note that in the first three areas commentators have taken a broad range of positions, and neither the Supreme Court nor the lower courts have done much to provide clarity. ${ }^{31}$ Similarly, the IRS has not done much to develop the concept of "fundamental" public policy. ${ }^{32}$ In fact, its subsequent applications of Bob Jones University have been almost entirely limited to situations involving criminal activities, racial discrimination relating to education, or, less commonly, to other contexts where such discrimination "can reasonably be expected to aggravate the disparity in the educational, economic, or social levels of [a racial] group when compared with society as a whole."

However, unlike the courts, the IRS has attempted to resolve the latter three areas of uncertainty. First, it has focused on activities as evidence of purposes as opposed to considering either activities or purposes in isolation. ${ }^{34}$ More specifically, it has taken the position that acts that are illegal or contrary to public policy and that are also a substantial part of an organization's activities (taking into account the nature of the acts as well as their quantity) demonstrate a disqualifying non-charitable purpose..$^{35}$ Second, it has taken the position that activities can be contrary to fundamental public policy even absent violations of any federal, state, or local laws, providing

30. See, e.g., supra note 14.

31. See id.

32. See infra notes 33-34.

33. IRS Tech. Adv. Mem. 89-10-001 (Mar. 10, 1989); IRS Gen. Couns. Mem. 39,792 (Aug. 17, 1987). See generally Samuel D. Brunson \& David J. Herzig, A Diachronic Approach to Bob Jones: Religious Tax Exemptions after Obergefell, 92 IND. L.J. 1175, 1189-95 (2017).

34. IRS, Activities That are Illegal or Contrary to Public Policy, in EXEMPT ORGANIZATIONS CONTINUING PROFESSIONAL EDUCATIONAL TECHNICAL INSTRUCTION PROGRAM FY 1985, at 109-10 (1984), https://www.irs.gov/pub/irs-tege/eotopicj85.pdf [https://perma.cc/6LSH-XWS6].

35. Id.; Jean Wright \& Jay H. Rotz, Illegality and Public Policy Considerations, in EXEMPT ORGANIZATIONS CONTINUING PROFESSIONAL EDUCATIONAL TECHNICAL INSTRUCTION PROGRAM FY 1994, at 2 (1993), https://www.irs.gov/pub/irs-tege/eotopicl94.pdf [https://perma.cc/VFG2-BENE]. 
the situations in Bob Jones University as examples. ${ }^{36}$ Relatedly, the IRS distinguishes between illegal activity, by which it means activity in violation of federal, state, or local statutes (usually criminal ones), ${ }^{37}$ and activity contrary to fundamental public policy, for which it implicitly includes the modifier "federal," consistent with the Supreme Court's focus on federal policy in the Bob Jones University case. ${ }^{38}$ Third and finally, the IRS has taken the position that churches should not be treated differently from any other type of organization claiming the tax benefits available to charities: if churches engage in "substantial" activities that are illegal or contrary to fundamental public policy, then they are disqualified from receiving those benefits. ${ }^{39}$ The question then becomes what activities of a church might be illegal or contrary to fundamental public policy, with racial discrimination (assuming no church-run school) not necessarily rising to that level..$^{40}$

This last IRS position is not without its critics. For example, Professor Jerold Friedland concludes that the above-quoted footnote "suggests the Court intended to reserve its judgment on both the public policy and first amendment issues with respect to racially discriminatory churches. ${ }^{\prime 11} \mathrm{He}$ therefore leaves open the possibility that the Court might conclude that applying the Bob Jones University holding to churches violates the First Amendment. And in an analysis written shortly before the Supreme Court's decision, Professor Douglas Laycock argued that the First Amendment, and

36. IRS, supra note 34, at 114; Wright \& Rotz, supra note 35, at 3.

37. See Rev. Rul. 75-384, 1975-2 C.B. 204 (violations of local criminal ordinances); IRS, supra note 34, at 110-11; Hatfield et al., supra note 14, at 3, 95-100; Wright \& Rotz, supra note 35 , at 8,10 .

38. See Bob Jones Univ., 461 U.S. at 593-95; IRS, supra note 34, at 114-15; Wright \& Rotz, supra note 35 , at 3,9-10. This reading is also consistent with an earlier federal district court opinion that anticipated the Bob Jones University decision. See Green v. Connally, 330 F. Supp. 1150, 1163-64 (D.D.C. 1971) (focusing on federal public policy).

39. IRS, supra note 34, at 110, 116-18; see also Wright \& Rotz, supra note 35, at 19-20.

40. See Schachner, supra note 28 , at 310.

41. Jerold A. Friedland, Constitutional Issues in Revoking Religious Tax Exemptions: Church of Scientology of California v. Comm'r, 37 U. FLA. L. REv. 565, 587 (1985). 
particularly the concept of church autonomy, generally prohibited government interference with the internal affairs of churches, including interference in the form of revoking the tax-exempt status of racially discriminatory churches. ${ }^{42}$

We will return to the first three areas of uncertainty in Part II, when we discuss current and likely future areas of conflict between churches and fundamental public policy. As for the application of the Bob Jones University decision to churches generally, we will return to that unsettled issue in Part IV, after considering the basis for the tax benefits provided to churches. Before considering the tax treatment of churches more generally, however, it is worth describing the instances where the IRS has applied Bob Jones University specifically to churches.

\section{B. Subsequent Rulings and IRS Actions Involving}

\section{Churches}

The IRS has rarely applied Bob Jones University to churches, perhaps taking to heart the now forty-year-old admonition of Professor Stephen Schwarz that "in this delicate area, the Internal Revenue Service would do well to halt at the gates of the church, preserving valuable religious and associational rights in the process." ${ }^{\prime 3}$ Nevertheless, the IRS has entered those gates while waving the Bob Jones University flag a handful of times.

In Synanon Church v. United States, ${ }^{44}$ the U.S. District Court for the District of Columbia noted that, while the religious status of the organization at issue was in dispute, "[e]ven a bona fide church that

42. Douglas Laycock, Tax Exemptions for Racially Discriminatory Religious Schools, 60 TEX. L. REV. 259, 261-63 (1982).

43. Stephen Schwarz, Limiting Religious Tax Exemptions: When Should the Church Render unto Caesar, 29 U. FLA. L. REV. 50, 91 (1976).

44. 579 F. Supp. 967 (D.D.C. 1984), aff'd 820 F.2d 421 (D.C. Cir. 1987). 
failed the ... Bob Jones test would not be eligible for tax exemption." 45 It "reluctantly" declined, however, to apply Bob Jones University to resolve the case based on acts and threats of physical violence by the organization's leaders and members because the organization's fraud on the court provided a sufficient basis for ruling in the government's favor. ${ }^{46}$

In Church of Scientology of California v. Commissioner, ${ }^{47}$ the U.S. Tax Court upheld the revocation of tax-exempt status from the Church of Scientology of California based in part on the proven conspiracy by church leaders to impede the IRS in violation of federal criminal law. These actions, the court concluded, demonstrated the church's substantial illegal purpose. ${ }^{48}$ In doing so, the court rejected the church's argument that revocation was not permitted under the First Amendment because a less restrictive means-criminal prosecution of the individual offenders - was available to address the illegal activities. ${ }^{49}$ However, on appeal the U.S. Court of Appeals for the Ninth Circuit did not apply Bob Jones University because it affirmed the Tax Court's decision on other grounds. ${ }^{50}$

The IRS also revoked the tax-exempt status of the racist World Church of the Creator, apparently based on the reasoning the Court upheld in Bob Jones University, although the IRS likely made its decision before the Court issued that opinion. ${ }^{51}$ That organization was, however, unable to challenge that revocation in court because

45. Id. at 971 .

46. Id. at 978-79 (dismissing the case with prejudice because of fraud on the court and so not reaching the merits of the government's tax exemption decision).

47. 83 T.C. 381 (1984), aff'd 823 F.2d 1310 (9th Cir. 1987).

48. Id. at $502-09$.

49. Id. at 503, 506-07.

50. Church of Scientology of Cal., 823 F.2d at 1315.

51. See Te-Ta-Ma Truth Foundation-Family of Uri, Inc. v. World Church of the Creator, 297 F.3d 662, 663-64 (7th Cir. 2002) (citing Church of the Creator v. Comm'r, 707 F.2d 491 (11th Cir. 1983)). 
of a procedural failure, and so the IRS's substantive position was not subject to judicial review..$^{52}$

In 1988 the IRS issued a General Counsel Memorandum discussing the proposed revocation of a church's tax-exempt status because of how it operated a school. ${ }^{53}$ Having found that the church failed to meet its burden of showing that it operated the school in a bona fide nondiscriminatory manner, the IRS further concluded that since the church and school were apparently a single legal entity that was both an educational institution and a religious institution-a characterization the Supreme Court had applied to Bob Jones University in its decision-it was appropriate to revoke the tax-exempt status of that legal entity (and therefore of the church as well as of the school).${ }^{54}$ While the Memorandum was redacted to conceal the identity of the church and school involved, as required by taxpayer privacy laws, ${ }^{55}$ the church almost certainly was the one associated with the Goldsboro Christian Schools involved in the Bob Jones University case. ${ }^{56}$

Finally, in 2013 the IRS denied an application for recognition of exemption under Section 501(c)(3) from a church with polygamy in

52. Church of the Creator, 707 F.2d at 492-93.

53. I.R.S. Gen. Couns. Mem. 39,754 (July 7, 1988).

54. Id.; see also Robert J. Desiderio, PLANNING TAX-EXEMPT ORGANIZATIONS $§ 14.04$ (2018) (stating a church can avoid the application of this Memorandum and so protect its own tax-exempt status by making a school that does not meet the requirements for exemption a separate legal entity). This position was consistent with the IRS's announced position prior to the Bob Jones University decision. See Rev. Rul. 75-231, 1975-1 C.B. 158.

55. See I.R.C. $\$ 6103$ (2018); Taxation with Representation Fund v. IRS, 646 F.2d 666, 668,676 (D.C. Cir. 1981) (affirming order requiring public disclosure of General Counsel's Memoranda under the Freedom of Information Act subject to redacting tax return information protected by I.R.C. $§ 6103$ ).

56. See Oliver S. Thomas, The Power to Destroy: The Eroding Constitutional Arguments for Church Tax Exemption and the Practical Effect on Churches, 22 CUMB. L. REv. 605, 614 nn.57-58 (1992); Albert B. Crenshaw, IRS Revokes Church Tax Exemption for First Time, WASH. POST (Dec. 7, 1988), https:/www.washingtonpost.com/archive/business/1988/ 12/07/irs-revokes-church-tax-exemption-for-first-time/041f2d82-4706-4a2b-b0e4a83e2e8ff963/ [https://perma.cc/Q6C4-T9CT]. 
its beliefs and practices. ${ }^{57}$ The IRS based the denial both on the organization's violation of state criminal law-a jury had found a leader of the group guilty of bigamy - and of the federal (presumably fundamental) policy against bigamy..$^{58}$

These five instances therefore involved illegal criminal activity in three cases, an uncertain basis for revocation in the fourth case, and a church's operation of a racially discriminatory school (and indeed a school that almost certainly was one of the subjects of the Bob Jones University decision) in the fifth case. Therefore, despite the IRS's general statements that Bob Jones University applies to churches, ${ }^{59}$ in practice the IRS has applied that case to churches only in very limited circumstances. It is unclear, however, whether this reluctance flows from a general sense of caution in this fraught area, a more specific concern about avoiding any appearance of selectively targeting minority religious faiths, or a lack of instances where the IRS knows there is a plausible case that a church is in fact acting contrary to fundamental public policy.

\section{CHURCHES AND FUNDAMENTAL PUBLIC POLICY}

This Part explores whether there are any current or likely future conflicts between churches and fundamental public policy-even if the IRS has so far not chosen to act with respect to them-that would require considering if and how Bob Jones University applies to churches. While the IRS and the courts have also applied the illegality aspect of the Bob Jones University holding to churches, our focus will be on the contrary-to-fundamental-public-policy aspect, to the extent it goes beyond illegality. This is because recent instances of churches engaging in clearly illegal behavior appear to be extremely rare, which is not surprising given that such behavior could result in penalties for churches and their leaders that are much more severe than any loss of tax benefits. For example, the 
First Church of Cannabis decided to avoid a confrontation with Indiana law enforcement authorities over sacramental use of marijuana even though it had already secured recognition of its tax-exempt status from the IRS. ${ }^{60}$ That said, we will revisit the topic of illegality in Part $V$, including whether only criminal illegality should be a basis for a church losing tax benefits.

We begin by considering whether Bob Jones University should be limited to racial discrimination, given the arguably unique history of that form of discrimination in the United States. We conclude that it should not, and therefore we then consider discrimination on various other often prohibited grounds, including, but not limited to, sexual orientation. We also consider the sanctuary church movement that seeks to protect undocumented immigrants from enforcement of federal immigration laws and other possible conflict areas.

\section{A. Why the Uniqueness of Racial Discrimination in Educa- tion Should Not Control}

The IRS and ultimately the Supreme Court recognized that there was a fundamental public policy against racial discrimination in education. ${ }^{61}$ However, the Court also noted that "[f]ew social or political issues in our history have been more vigorously debated and more extensively ventilated than the issue of racial discrimination, particularly in education."62 As Professor Olatunde Johnson states,

60. See Mark Alesia \& Gabby Ferreira, Humor, love, police a strange mix at Cannabis Church, INDYSTAR (July 1, 2015), https://www.indystar.com/story/news/2015/07/01/humor-police-presence-mixed-cannabis-church-site/29561919/ [https://perma.cc/ND4NGGGJ]; John Tuohy, First Church of Cannabis wins IRS nonprofit status, INDYSTAR (June 2, 2015), https://www.indystar.com/story/news/2015/06/02/first-church-cannabis-winsirs-nonprofit-status/28357541/ [https://perma.cc/JBE9-3L8T]. While not required to apply for recognition of exemption under I.R.C. $\S 501(\mathrm{c})(3)$, churches may voluntarily choose to do so as the First Church of Cannabis apparently did. See I.R.C. § 508(c)(1)(A) (exception from notification requirement to claim tax exemption under I.R.C. § 501(c)(3)); INTERNAL REVENUE SERVICE, TAX GUIDE FOR CHURCHES \& RELIGIOUS ORGANIZATIONS, PUBLICATION 1828, at 3 (2015).

61. Bob Jones Univ. v. United States, 461 U.S. 574, 595 (1983).

62. Id. 
"the historical context... provides ... crucial context for understanding the Court's decision." 63 That context included de facto continuing segregation in education through the creation of numerous private schools, such as the Goldsboro Christian Schools, that limited their students to whites, often with the encouragement and even financial support of southern state governments. ${ }^{64}$

None of the policies discussed below, and particularly not the policies relating to sex discrimination and immigration that are the most likely to qualify as fundamental currently, have a similar context. The longstanding religious teachings relating to the roles of men and women both in religious leadership and more generally are not being used to justify the creation of numerous segregated or discriminatory institutions designed to frustrate the policy against sex discrimination, although it must be acknowledged that the effect of those teachings has been and still is significant within those faiths that follow them. ${ }^{65}$ Nor are longstanding religious teachings relating to welcoming strangers and foreigners being used to support the creation of new institutions to frustrate immigration laws, and the number of sanctuary churches and sheltered immigrants appears to be relatively small. ${ }^{66}$ If, therefore, Bob Jones

63. Johnson, supra note 14, at 128; see also KENT GREENAWALT, EXEMPTIONS: NECESSARY, JUSTIFIED, OR MISGUIDED? 163-67 (2016) (distinguishing opposing same-sex marriage from opposing interracial marriage in the context of determining appropriate exemptions from anti-discrimination laws, in part based on the history of racial discrimination in the United States).

64. Johnson, supra note 14, at 131; see also Johnny Rex Buckles, The Sexual Integrity of Religious Schools and Tax Exemption, 40 HARV. J.L. \& PUB. POL'Y 255, 317 (2017); Galston, supra note 14, at 319; Herzig \& Brunson, supra note 14, at 1116; Karla W. Simon, The TaxExempt Status of Racially Discriminatory Religious Schools, 36 TAX L. REV. 477, 477 (1981); Sally Wagenmaker, Why Religious Organizations Shouldn't Lose Tax-Exempt Status Based on Public Policy, Post-Obergefell, at 31 (2018), https://papers.ssm.com/sol3/papers.cfm?abstract_id=3104688 [https://perma.cc/6TAP-53AW].

65. See infra note 91 and accompanying text.

66. See Thomas Scott-Railton, Note, A Legal Sanctuary: How the Religious Freedom Restoration Act Could Protect Sanctuary Churches, 128 YALE L.J. 408, 421-23 (2018); Kaitlyn Schallhorn, What's a sanctuary church? A look at the policy and its legality in the US, FOX NEwS (July 17, 2018), https:/www.foxnews.com/politics/whats-a-sanctuary-church-alook-at-the-policy-and-its-legality-in-us [https://perma.cc/E4KK-YWGD]; infra notes 114,115 , and accompanying text. 
University is viewed as limited not only to "fundamental" public policies but also to situations that are historically unusual if not unique, in part because there is a concerted, large-scale effort to frustrate the policy, it does not appear any of the current conflicts rise to this level. ${ }^{67}$

There are at least two significant problems with this approach, however. First, that is simply not what the Court (or the IRS) said with respect to the contrary-to-fundamental-public-policy doctrine. On its face, that doctrine provides that once an otherwise charitable organization's activities are shown to be contrary to fundamental public policy, and if those activities rise to a significant enough level relative to the organization's overall activities, then the organization loses the tax benefits that usually come with that status. ${ }^{68} \mathrm{It}$ does not matter whether the organization or its activities are new, whether the organization is an outlier or part of a larger movement opposing the policy at issue, or whether there are any other distinguishing historical characteristics. ${ }^{69}$ Furthermore, this understanding of the doctrine is consistent with the overall approach of the IRS, and the underlying statutes, with respect to tax benefits; organizations qualify or fail to qualify based on their characteristics and actions, not generally based on the larger context in which they and their actions exist. ${ }^{70}$

Second, this approach creates another ambiguous line that has to be drawn to determine if the doctrine applies. It would require the IRS and courts to wrestle not only with whether a given public pol-

67. See David A. Brennen, A Diversity Theory of Charitable Tax Exemption-Beyond Efficiency, Through Critical Race Theory, Toward Diversity, 4 PITT. TAX REV. 1, 53-54 (2006); Buckles, supra note 64, at 311-12; Shannon Weeks McCormack, Taking the Good with the Bad: Recognizing the Negative Externalities Created by Charities and Their Implications for the Charitable Deduction, 52 ARIz. L. REV. 977, 1013 (2010). But see John D. Inazu, The Four Freedoms and the Future of Religious Liberty, 92 N.C. L. REv. 787, 837-43 (2014) (rejecting the argument that racial discrimination is distinctly worse as compared to other forms of discrimination such that the government is justified and permitted to prohibit racial but not other forms of discrimination by private groups).

68. See Bob Jones Univ. v. United States, 461 U.S. 574, 586, 591-92 (1983).

69. See id.

70. I.R.C. §§ 501(a), (c)(3) (2018); Treas. Reg. §§ 1.501(c)(3)-1(a)-(c) (2018). 
icy is "fundamental," and whether an otherwise charitable organization's actions contrary to that policy are relatively significant, but also whether those actions are somehow similar historically to racial discrimination. Such a determination is likely one that the IRS is even more ill-suited to make than the fundamental public policy determination. While the IRS is required to make the latter determination based on the position it asserted and the Court upheld in Bob Jones University, that decision does not require the former determination. This distinguishing based on historical context approach therefore appears to be both legally unjustifiable and impractical. $^{71}$

We therefore need to consider whether conflicts exist now, or are likely to exist in the future, between the practices of a significant number of churches and fundamental public policies.

B. Discrimination in Employment, Services, and Membership

This Part considers the types of discrimination currently disfavored in at least some contexts by federal law to determine whether federal policy could either currently or in the near future rise to the level of a fundamental public policy and, if it could, whether that policy would conflict with the practices of a significant number of churches..$^{72}$ More specifically, this Part details that while racial discrimination by private individuals and organizations is widely disfavored, federal law does not prohibit such discrimination in all contexts. For example, in the employment context, federal law reaches only organizations that have a certain number of employees. ${ }^{73}$ Federal law also does not generally prohibit racial discrimination with respect to the membership of private organizations, although in the wake of a court decision concluding that social clubs

71. See Brunson \& Herzig, supra note 33, at 1206-07 (rejecting treating Bob Jones University as an outlier).

72. See id. at 1213-15 (considering the use of the Civil Rights Act of 1964 to establish a framework for applying the contrary-to-fundamental-public-policy doctrine).

73. 42 U.S.C. $\$ 2000 \mathrm{e}$ (b) (2018) (defining employer in the context of civil rights legislation as having fifteen or more employees). 
could qualify for tax exemption even if they discriminated on the basis of race, Congress decided to deny exemption to social clubs if they have a written policy that discriminates on the basis of race, color, or religion. ${ }^{74}$ And federal law prohibits racial discrimination in the provision of goods or services only in certain industries that provide public accommodations. ${ }^{75}$ Similar limitations apply to federal law relating to disfavored discrimination of other types, such as those based on ethnicity, national origin, sex, religion, age, disability, and veteran status. ${ }^{76}$

In addition, the Supreme Court has found that the First Amendment requires what has come to be known as a "ministerial exception" to employment discrimination laws in order to protect the ability of churches and other religious organizations, such as religious schools, to select their leaders. ${ }^{77}$

1. Racial, Ethnic, and National Origin Discrimination

The employment context provides the strongest example of an anti-discrimination policy that has become fundamental. As was the case with racial discrimination in education when Bob Jones University was decided, federal government animus toward racial, ethnic, and national origin discrimination in employment can be found in a wide range of congressionally enacted statutes, executive

74. See I.R.C. § 501(i); McGlotten v. Connally, 338 F. Supp. 448, 457-59 (D.D.C. 1972); Jim Langley \& Conrad Rosenberg, Social Clubs - IRC 501(c)(7), in EXEMPT ORGANIZATIONS CONTINUING PROFESSIONAL EDUCATION (CPE) TECHNICAL INSTRUCTION PROGRAM FOR FISCAL YEAR 1996, at 15 (1996), https://www.irs.gov/pub/irs-tege/eotopicc96.pdf [https://perma.cc/DU2H-7LVB].

75. See 42 U.S.C. $\$ 2000$ a (2018).

76. See, e.g., id. $\S 12101$ (2018). But it is worth noting that not all types of discrimination are or should be prohibited. See generally Richard W. Garnett, Religious Freedom and the Nondiscrimination Norm, in MATTERS OF FAITH: RELIGIOUS EXPERIENCE AND LEGAL RESPONSE (Austin Sarat ed., forthcoming) (2012), https://papers.ssrn.com/sol3/papers.cfm?abstract_id=2087599 [https://perma.cc/Y8W8-LG6B].

77. Our Lady of Guadalupe School v. Morrissey-Berru, 140 S. Ct. 2049, 2060 (2020); Hosanna-Tabor Evangelical Lutheran Church \& School v. EEOC, 565 U.S. 171, 188-89 (2012). 
branch pronouncements, and judicial decisions. ${ }^{78}$ The Court has, as noted previously, created a ministerial exception to these laws for the employment of ministers by religious organizations under the First Amendment. ${ }^{79}$ That the First Amendment may prohibit governments from flatly prohibiting such discrimination with respect to ministerial employment does not, however, necessarily mean it prohibits governments from conditioning tax benefits on not engaging in such discrimination.

But it is hard to identify any churches, much less a significant number, that openly and defiantly discriminate on the basis of race, ethnicity, or national origin in employment. ${ }^{80}$ The denominations that historically were most supportive of first slavery and then racial segregation, such as the Southern Baptist Convention, have now denounced racial discrimination in the strongest terms. ${ }^{81}$ And the denominations that historically have been affiliated with a particular racial minority, such as the National Baptist Convention, arguably do not run afoul of this federal policy because any bias they have favors historically disadvantaged racial minorities. ${ }^{82}$ This is

78. See David A. Brennen, The Power of the Treasury: Racial Discrimination, Public Policy, and "Charity" in Contemporary Society, 33 U.C. DAVIS L. REV. 389, $403-04$ (2000).

79. See supra note 77 and accompanying text.

80. One minor exception may be churches with strong ethnic associations, such as Orthodox Jewish synagogues and Russian or Greek Orthodox churches, that limit membership to persons of the relevant ethic background or at least place additional membership qualifications on a believer from outside the relevant ethnic group. See Heather Miller Rubens, "Something Has Gone Wrong": The JFS Case and Defining Jewish Identity in the Courtroom, 29 MD. J. INT'L L. 366, 368-69 (2014) (United Kingdom court decision finding that the denial of preferential consideration for an applicant to a religious school was ethnic discrimination when it was based on their mother not being considered Jewish and their unwillingness to undergo an Orthodox conversion); Eugene Volokh, Freedom of Expressive Association and Government Subsidies, 58 STAN. L. REV. 1919, 1921 (2006) (asserting “Orthodox Jewish synagogues discriminate based on ethnicity ... in choosing rabbis and members").

81. See SOUTHERN BAPTIST CONVENTION, RESOLUTION ON RACIAL RECONCILIATION ON THE 150TH ANNIVERSARY OF THE SOUTHERN BAPTIST CONVENTION (1995), https://www.sbc.net/resource-library/resolutions/resolution-on-racial-reconciliationon-the-150th-anniversary-of-the-southern-baptist-convention/ [https://perma.cc/QMU9-7QQD].

82. See Brennen, supra note 78 , at 439 (concluding that there is no clearly established federal public policy against affirmative action). 
not to say there have not been credible allegations of isolated instances of racism; for example, in June 2018 the Southern Baptist Convention expelled a church based on "clear evidence of the church's intentional discriminatory acts." ${ }^{83}$ So while it is possible that out of the hundreds of thousands of churches in the United States $^{84}$ the IRS might become aware of a handful that engage in intentional racial discrimination in employment, the relative rareness of such practices among churches, the assumption that such churches are likely to be small, and the First Amendment issues raised by the existence of the ministerial exception, may understandably lead the IRS to decide to deploy its limited enforcement resources elsewhere. Any conflict in this particular area would therefore be rare to nonexistent.

With respect to the provision of goods and services, the federal government also has a strong policy against racial discrimination, but only with respect to the provision of certain goods and services in "a place of public accommodation" that affects interstate commerce or is supported by a state government (such as hotels, restaurants, and entertainment venues). ${ }^{85}$ The limited reach of most churches and the lack of direct state financial support for them would seem to place them beyond the scope of that policy. While hypothetically one can imagine a church that operated, for example, a hotel open to the public, similar to the Second Baptist Church of Goldsboro's operating the Goldsboro Christian Schools (through the same legal entity as the church), as a practical matter such a situation is likely to be rare or nonexistent. (In addition, when a

83. Carma Henry, Georgia Church Expelled from Southern Baptist Convention Over Racial Discrimination Charges, WESTSIDE GAZETTE (June 13, 2018), https://thewestsidegazette.com/georgia-church-expelled-from-southern-baptist-convention-over-racial-discrimination-charges/ [https://perma.cc/X84D-KKNA].

84. Fast Facts About American Religion, HARTFORD INST. FOR RELIGION RESEARCH, http://hirr.hartsem.edu/research/fastfacts/fast_facts.html\#numcong [https://perma.cc/W96W-SADP].

85. See supra note 75 and accompanying text. Of course it is not always clear whether a group is providing a "public accommodation." See, e.g., Nelson Tebbe, Associations and the Constitution: Four Questions about Four Freedoms, 92 N.C. L. REV. 917, 924-27 (2014). 
church engages in racial discrimination that "can reasonably be expected to aggravate the disparity in the educational, economic, or social levels of [a racial] group when compared with society as a whole," 86 such as by operating a racially discriminatory school, the government's interest in extending the contrary-to-fundamentalpublic-policy doctrine to the church is arguably strong enough to overcome the arguments advanced in this Article for not doing so with respect to churches generally. ${ }^{87}$ )

Finally, with respect to membership, the IRS Chief Counsel's office has concluded that "exclud[ing] from participation in or den[ying] the benefits of a program or activity to individuals solely on the basis of race so that it can be reasonably be expected to aggravate the disparity in the educational, economic, or social levels of that group when compared with society as a whole" violates fundamental public policy ${ }^{88}$ It is not clear, however, that this conclusion extends to membership in a church or attendance at a church gathering, absent clear evidence such membership or attendance provides significant educational, economic, or social benefits, particularly given the First Amendment associational as well as free exercise concerns raised by such an extension. Therefore, even if the IRS became aware of a church that intentionally engaged in racial discrimination with respect to its membership or attendancewhich appears to be a rare circumstance under any conditions-it likely would rightly conclude that such behavior does not rise to the level of being contrary to fundamental public policy. ${ }^{89}$ Therefore, while prohibiting racial discrimination in some, but not all,

86. I.R.S. Tech. Adv. Mem. 89-10-001 (Mar. 10, 1989); I.R.S. Gen. Couns. Mem. 39,792 (Aug. 17, 1987).

87. See infra text accompanying note 367.

88. Supra note 33.

89. While the IRS did revoke the tax-exempt status of a racist church apparently based on Bob Jones University, both IRS's reasoning and the facts it deemed relevant are unclear. See supra note 52 and accompanying text. It is therefore impossible to tell if that decision was inconsistent with the above-cited I.R.S. General Counsel Memorandum, which Memorandum was later in time and so presumably would be a better indication of the IRS's position in this respect under any conditions. See supra note 33 and accompanying text. 
contexts almost certainly is a fundamental public policy, an actual conflict is unlikely in those contexts because of the lack of such behavior by a significant number of churches. ${ }^{90}$

\section{Sex Discrimination}

While intentional racial discrimination appears to be rare among churches, intentional sex discrimination is much more widespread. The most obvious example is the position taken by many religious institutions, including the Catholic Church, a significant number of Protestant churches, more theologically conservative Jewish synagogues, and some bodies in other religions, that certain leadership roles are reserved for men. Some faiths also explicitly teach that women and men have different roles in society more generally. ${ }^{91}$ Beyond explicit policies with respect to leadership and societal roles, there has also been at least one recent public dispute in a major denomination relating to the treatment of women. In a decision that was controversial within that denomination, a Southern Baptist seminary decided to fire a longtime Southern Baptist leader in the wake of criticism for his alleged treatment of and teachings about women, including how he responded to two stüdents who

90. Outside of the church context, there has been speculation (but no IRS rulings or other guidance) that tax-exempt hate groups promoting white supremacy may now run afoul of the contrary-to-fundamental-public-policy doctrine, notwithstanding First Amendment concerns. See, e.g., David J. Herzig \& Samuel D. Brunson, Opinion, White Supremacist Groups Don't Deserve Tax Exemptions, N.Y. TIMES (Aug. 29, 2017), https://www.nytimes.com/2017/08/29/opinion/white-supremacists-tax-exemptions.html [https://nyti.ms/2weafrQ]; Darryll K. Jones, House of Representatives Passes Resolution Condemning Hate Speech: Fundamental Public Policy Yet?, NONPROFIT LAW PROF BLOG (Jan. 16, 2019), https://lawprofessors.typepad.com/nonprofit/2019/01/ house-of-representatives-passes-resolution-condemning-hate-speech-fundamentalpublic-policy-yet.html [https://perma.cc/9GTF-VHMM].

91. See, e.g., THE CHURCH OF JESUS CHRIST OF LATTER-DAY SAINTS, THE FAMILY: A PROCLAMATION TO THE WORLD (1995) (teaching that, "[b]y divine design, fathers are to preside over their families in love and righteousness and are responsible to provide the necessities of life and protection for their families. Mothers are primarily responsible for the nurture of their children"). See generally Mary E. Becker, The Politics of Women's Wrongs and the Bill of "Rights": A Bicentennial Perspective, 59 U. CHI. L. REV. 453, 458 n.30 \& 459-69 (1992); Caroline Mala Corbin, Expanding the Bob Jones Compromise, in LEGAL RESPONSES TO RELIGIOUS PRACTICES IN THE UNTTED STATES 123, 133, 147-49 (Austin Sarat ed., 2012). 
alleged they had been sexually assaulted by others and his teachings regarding "the Bible's view of women and his belief that spousal abuse is not grounds for divorce."

The key question in this context is therefore whether federal government policies relating to sex discrimination, in the employment context and beyond, have become fundamental. The Court in Bob Jones University made this determination with respect to racial discrimination in education by looking at the extent of actions of the three branches of the federal government and the time period over which those branches consistently opposed such discrimination. ${ }^{93}$ With respect to sex discrimination, Congress included in Title VII of the Civil Rights Act of 1964 a prohibition on discrimination in employment on the basis of sex and a year earlier enacted the Equal Pay Act, which prohibited paying women and men unequally for equal work. ${ }^{94}$ It also enacted Title IX of the Education Amendments of 1972, which prohibited sex discrimination in education programs receiving federal funds and broadened the reach of that provision in 1988, including refusing to exclude churches. ${ }^{95}$

While initially the federal courts resisted a robust prohibition on sex discrimination under the Equal Protection Clause of the Fourteenth Amendment, for the past forty or so years state action involving such discrimination has been subject to an "intermediate" level of scrutiny (somewhere between the "strict scrutiny" that applies to racial discrimination and the rational basis scrutiny that applies generally). ${ }^{96}$ This level of scrutiny led to, for example, the Supreme Court concluding that the male-only admissions policy of

92. See Sarah Pulliam Bailey, Southern Baptist seminary drops bombshell: Why Paige Patterson was fired, WASH. POST (June 1, 2018), https://www.washingtonpost.com/news/acts-of-faith/wp/2018/06/01/southern-baptist-seminary-dropsbombshell-why-paige-patterson-was-fired [https://perma.cc/ST7G-FB5X].

93. Bob Jones Univ. v. United States, 461 U.S. 574, 593-95 (1983); see also Hatfield et al., supra note 14 , at 3 .

94. See 29 U.S.C. $\$ 206(d)(2018) ; 42$ U.S.C. $§ 2000 \mathrm{e}-2$ (a) (2018).

95. See 20 U.S.C. \$§1681-1688 (2018); Stephen L. Mikochik, Caesar's Coin: Federal Funds, Civil Rights, and Churches, 9 J.L. \& RELIGION 193, 193-94 (1991).

96. See Katie R. Eyer, The Canon of Rational Basis Review, 93 NOTRE DAME L. REV. 1317, 1328-29 (2018). 
the Virginia Military Institute, a public university, violated the Constitution. ${ }^{97}$ The executive branch not only has long prohibited sex discrimination in government employment generally but, for example, has increasingly permitted women to seek combat positions in the military, most recently graduating the first female Marines from its infantry officer course in the wake of the decision to open all combat roles to women. ${ }^{98}$ Even without the ratification of the Equal Rights Amendment (ERA) to the Constitution, ${ }^{99}$ it therefore appears that prohibiting sex discrimination, at least in the employment context, is now a fundamental public policy since all three branches of the federal government now have a decades-long, broad, and consistent policy of rejecting it. ${ }^{100}$ While the IRS has in the past decided that sex discrimination was not "clearly contrary to public policy," 101 those decisions do not reflect these more recent legal developments. Some commentators have therefore called upon the IRS to revoke the tax-exempt status of religious organizations that engage in this type of discrimination. ${ }^{102}$

97. United States v. Virginia, 518 U.S. 515, 519 (1996).

98. See Kevin Lui, In a Landmark First, the U.S. Marines Now Has a Female Infantry Officer, TIME (Sept. 26, 2017), https://time.com/4956767/us-marines-first-female-infantryofficer [https://perma.cc/S2KV-EL68].

99. The ratification of the ERA by Virginia on January 15, 2020 does not necessarily mean the ERA is now part of the Constitution, both because Congress placed a time limit on ratification that expired in 1982 and because several states have rescinded their previous ratifications. Darlene Ricker, What does Equal Rights Amendment ratification in Virginia mean for its chances?, ABA JOURNAL (Jan. 16, 2020), http://www.abajournal.com/web/article/era-ratification-in-virginia-doesnt-seal-its-fate-timing-is-everything [https://perma.cc/VL3P-3F2Q].

100. See Hatfield et al., supra note 14 , at 40 .

101. See, e.g., I.R.S. Tech. Adv. Mem. 77-44-007 (July 28, 1977); Moritz v. Comm'r, 55 T.C. 113, 115 (1970).

102. See, e.g., Becker, supra note 91, at 485; Corbin, supra note 91, at 134-35, 156-58; cf. Boris I. Bittker \& Kenneth M. Kaufman, Taxes and Civil Rights: "Constitutionalizing" the Internal Revenue Code, 82 YALE L.J. 51, 61-63 (1972) (arguing that the tax benefits enjoyed by most tax-exempt organizations are sufficient to render them state actors and so prohibited from discriminating on various grounds, including sex). But see COREY BRETTSCHNEIDER, WHEN THE STATE SPEAKS, WHAT SHOULD IT SAY? 134-36 (2012) (arguing that the position of at least some churches with respect to women and homosexual people is not so clearly opposed to the ideal of free and equal citizenship to justify removing their federal income tax benefits); Timothy J. Tracey, Bob Jonesing: Same-Sex 
So why has the IRS not acted in this area? A cynical explanation is that the IRS is much weaker politically than it was in the 1970s and so has no stomach for the backlash that would undoubtedly occur if it were to pursue such a controversial course of action. ${ }^{103} \mathrm{~A}$ more principled explanation is that the IRS has concluded that since such discrimination most commonly occurs with respect to the selection of religious leaders, the constitutionally based ministerial exception-not at issue in Bob Jones University - would prevent revoking the tax-exempt status of a religious organization that engages in such discrimination.

\section{Sexual Orientation Discrimination}

As is the case with sex discrimination, many faiths intentionally discriminate on the basis of either conduct associated with sexual orientation $^{104}$ or, less commonly, sexual orientation itself. ${ }^{105}$ Such discrimination is almost certainly more pervasive than sex discrimination, particularly given that many faiths believe that same-sex sexual relationships are inherently wrong, potentially disqualifying

Marriage and the Hankering to Strip Religious Institutions of Their Tax-Exempt Status, 11 FIU L. REV. 85, 92 (2015) (concluding without much discussion that sex discrimination is not contrary to fundamental public policy).

103. See generally Amy Moore, Rife with Latent Power: Exploring the Reach of the IRS to Determine Tax-Exempt Status According to Public Policy Rationale in an Era of Judicial Deference, 56 S. TEX. L. REV. 117, 138, 156-57 (2014) (arguing Chevron deference "has made the IRS rife with [latent] power" that Congress can choose to use when it becomes politically prudent).

104. See, e.g., CATECHISM OF THE CATHOLIC CHURCH, III 2357-2359 (2016) (distinguishing between homosexual conduct, which is "intrinsically disordered," and homosexual orientation); CHRISTIAN REFORMED CHURCH, HOMOSEXUALTTY, https:/www.crcna.org/welcome/beliefs/position-statements/homosexuality [https://perma.cc/UB7M-7H53] (distinguishing between individuals with a homosexual orientation, who can fully participate in the life of the church, and individuals practicing homosexuality, which is identified as sinful); SOUTHERN BAPTIST CONVENTION, RESOLUTION ON HOMOSEXUALITY, (1988), http://www.sbc.net/resource-library/resolutions/resolution-on-homosexuality-5/ [https://perma.cc/SHD4-69AF] (citations omitted) ("That we maintain that while God loves the homosexual and offers salvation, homosexuality is not a normal lifestyle and is an abomination in the eyes of God.").

105. Denny Burk, Is Homosexual Orientation Sinful?, ERLC (Feb. 18, 2014), https:/erlc.com/resource-library/articles/is-homosexual-orientation-sinful [https://perma.cc/YXW3-ZH9R] (arguing that homosexual orientation, and not just behavior, is sinful). 
those involved in such relationships from leadership roles and even from membership. ${ }^{106}$

However, commentators generally acknowledge that the federal government as a whole has not taken a consistent position against such discrimination, much less a strong and longstanding position sufficient to render this policy fundamental. ${ }^{107}$ Then-IRS Commissioner Koskinen appeared to take this position in 2015 as well, although he left the door open for reconsideration in the future. ${ }^{108}$ It is true that the Supreme Court in the recent case of Bostock v. Clayton County takes the position that Congress has long outlawed sexual orientation discrimination in employment by outlawing discrimination based on sex. ${ }^{109}$ But the repeated failure of Congress to enact an explicit prohibition on sexual orientation discrimination indicates at least some inconsistency in that branch's position. ${ }^{110}$ The Obergefell oral argument exchange was therefore at best premature; whether such discrimination by churches or other religious organizations ever truly becomes an "issue" the IRS and courts will need to wrestle with, it certainly does not rise to that level yet. This is

106. See Nicholas A. Mirkay, Losing Our Religion: Reevaluating the Section 501(c)(3) Exemption of Religious Organizations That Discriminate, 17 WM. \& MARY BILL OF RTS. J. 715, 717-19 (2009) (providing examples).

107. See, e.g., CONG. RSCH. SERV., R44244, RECOGNITION OF SAME-SEX MARRIAGE: IMPLICATIONS FOR RELIGIOUS OBJECTIONS 27 (2015); Brunson \& Herzig, supra note 33, at 1187; Buckles, supra note 64, at 308-10; Hatfield, supra note 14, at 90; Nicholas Mirkay, Is It Charitable to Discriminate: The Necessary Transformation of Section 501(c)(3) into the Gold Standard for Charities, 2007 WIS. L. REV. 45, 67-68 (2007); Tracey, supra note 102, at 92-93; Wagenmaker, supra note 64, at 24-27; Kirsten Berg \& Moiz Syed, Under Trump, LGBTQ Progress Is Being Reversed in Plain Sight, PROPUBLICA, (Nov. 22, 2019), https://projects.propublica.org/graphics/lgbtq-rights-rollback [https://perma.cc/S3V38L5M]. But see Dyllan Moreno Taxman, What About Bob? The Continuing Problem of Federally-Subsidized LGB Discrimination in Higher Education, 34 WIS. J.L. GENDER \& SOC'Y 39 , 64-65 (2019) (arguing that at least some forms of sexual orientation discrimination, such as not providing housing to same-sex married couple on the same basis as to oppositesex married couples, may now be contrary to fundamental public policy).

108. Hearing on Revisiting IRS Targeting: Progress of Agency Reforms and Congressional Options Before the Subcomm. on Oversight, Agency Action, Fed. Rts. and Fed. Cts. of the S. Comm. On the Judiciary, 114th Cong. (2015) (testimony of John Koskinen, Internal Revenue Service Commissioner).

109. Bostock v. Clayton Cty., 140 S. Ct. 1731, 1741 (2020).

110. See id. at 1822-24 (Kavanaugh, J., dissenting). 
particularly true given the protection provided to religiously motivated actions by the Religious Freedom Restoration Act, which, as the Court in Bostock noted, requires the government to have a compelling interest and use the least restrictive means of furthering that interest when substantially burdening a person's exercise of religion. ${ }^{111}$ But if it did rise to the level of a fundamental public policy at some point in the future, it would likely raise issues similar to those that the IRS currently faces with respect to sex discrimination and which will be explored further in Part V below.

\section{Other Forms of Discrimination}

The federal government also prohibits discrimination based on certain other grounds in some contexts, including employment. Such other grounds include religion, age, disability, and veteran status. ${ }^{12}$ Congress has understandably exempted religious organizations from the statutory prohibition on religious discrimination in employment, ${ }^{113}$ however, and there is no reason to conclude that the application of this particular policy would apply to churches in any other context. As for age and disability, as with racial discrimination, it appears that churches intentionally discriminating on these bases, whether in employment, provision of goods and services, or membership, are rare to nonexistent and therefore unlikely to create a significant conflict even if these policies are considered fundamental. Finally, one could imagine that those faiths with a pacifist tradition might discriminate against veterans in employment decisions, particularly for religious leaders, but it is more likely that they would discriminate based on whether an individual currently holds pacifist beliefs, which a veteran certainly could, rather than veteran status itself. So none of these federally disfavored bases for making decisions are likely to result in significant conflicts under Bob Jones University. 


\section{Protecting and Serving Undocumented Immigrants}

The increasingly heated debates over immigration raise a possible point of conflict outside of the discrimination context. Some churches have provided sanctuary for immigrants who are in this country illegally to protect them from possible deportation actions, based on the churches' religious convictions. ${ }^{114}$ To date the U.S. Department of Justice (DOJ) has criticized such actions but not pursued criminal or civil charges against the churches involved or their leaders. ${ }^{115}$ However, this was not the case in the 1980s, when the federal government successfully prosecuted individuals associated with the sanctuary movement. ${ }^{116}$ At least one commentator has argued pursuing such charges today might run afoul of the Religious Freedom Restoration Act, enacted in $1993 .{ }^{117}$ But should the IRS reconsider the tax benefits enjoyed by these churches under Bob Jones University even absent a finding by the DOJ or the courts that such activities are illegal?

114. See Schallhorn, supra note 66; Bobby Allyn \& Michel Marizco, Jury Acquits Aid Worker Accused Of Helping Border-Crossing Migrants in Arizona, NPR, (Nov. 21, 2019), https://www.npr.org/2019/11/21/781658800/jury-acquits-aid-worker-accused-of-helping-border-crossing-migrants-in-arizona [https://perma.cc/KLM5-HZFG] (describing how a humanitarian aid worker employed by Unitarian Universalist Church-affiliated ministry was acquitted of helping migrants). The legal history of sanctuary, particularly under common law, is lengthy and complicated. See generally JOHN BAKER, INTRODUCTION TO ENGLISH LEGAL HISTORY 553-54 (5th ed. 2019).

115. See Church Sanctuary for Illegal Aliens, 7 Op. O.L.C. 168 (1983), https://www.justice.gov/sites/default/files/olc/opinions/1983/10/31/op-olc-v007-

p0168_0.pdf [https://perma.cc/8RHM-NCP3] (criticizing practice and concluding any asserted legal defenses would be insufficient); Jason Hanna, Can churches provide legal sanctuary to undocumented immigrants, CNN (Feb. 17, 2017), https://www.cnn.com/2017/02/17/us/immigrants-sanctuary-churches-legality-trnd/index.html [https://perma.cc/Z9P2-CAWD] (reporting that "[i]n general, prosecutors probably won't go after a pastor" according to a former DOJ Office of Immigration Litigation assistant attorney general).

116. See generally Scott-Railton, supra note 66, at 417-19.

117. See id. at $419,433-49$. 
The history of immigration and immigration laws in the United States is lengthy and complicated, including with respect to enforcement of those laws. ${ }^{118}$ That said, Congress has certainly enacted laws limiting immigration and imposing penalties-primarily deportation-for violations of those laws, and the executive branch and the courts have a long history of enforcing and applying those laws and penalties. ${ }^{119}$ While it could be argued that the degree of enforcement varies among administrations, preventing the deportation of immigrants who are in the United States illegally appears to be contrary to fundamental public policy given the decades-long support of all three branches for deportation of many immigrants in the country illegally. ${ }^{120}$

Professor Ellen P. Aprill has considered this issue and is skeptical that the IRS would pursue revocation of tax exemption in sanctuary situations for a variety of reasons, including the lack of a clear finding of illegal activity by the DOJ, the fact that providing such sanctuary would likely be a relatively small part of a given church's activities, the limited resources of the IRS, and the historical unwillingness of the IRS to expand the application of the contraryto-fundamental-public-policy doctrine beyond racial discrimination in education. ${ }^{121}$ That said, she acknowledges that in theory the IRS could apply the contrary-to-fundamental-public-policy doctrine in this context to strip sanctuary churches of their federal tax

118. See generally WALTER A. EWING, AM. IMMIGRATION COUNCIL, IMMIGRATION POL'Y CTR., OPPORTUNITY AND EXCLUSION: A BRIEF HISTORY OF U.S. IMMIGRATION POLICY (2012), https://americanimmigrationcouncil.org/sites/default/files/research/opportunity_exclusion_011312.pdf [https://perma.cc/SRM7-QPGY].

119. See generally DANIEL KANSTROOM, DEPORTATION NATION: OUTSIDERS IN AMERICAN HISTORY (2007).

120. See, e.g., Alex Nowrasteh, Deportation Rates in Historical Perspective, CATO AT LIBERTY (Sept. 16, 2019), https://www.cato.org/blog/deportation-rates-historical-perspective [https://perma.cc/HZF4-7MKF] (finding more than 100,000 deportations per year under the administration of President Bill Clinton and every presidential administration since).

121. See Ellen P. Aprill, Religious Organizations, Refuge for Undocumented Immigrants, and Tax Exemption, Loyola Law School, Los Angeles Legal Studies Research Paper No. 2017-28, 1-5 (2017). 
benefits. ${ }^{122}$ This area therefore may be another current conflict under the contrary-to-fundamental-public-policy doctrine of Bob Jones University.

\section{Other Possible Conflicts}

Additionally, relatively rare situations in which a church runs afoul of Bob Jones University have arisen or could arise, including with respect to polygamy, marijuana, human rights violations, and sexual abuse. For example, the IRS has denied tax-exempt status as recently as 2013 to organizations that supported the (state law) criminal activity of polygamy, which the IRS concluded was also contrary to federal public policy. ${ }^{123}$ The IRS based those denials on multiple grounds, including that support of polygamy is necessarily both support for violating state laws and contrary to fundamental federal policy. ${ }^{124}$ Despite their illegality, plural marriages are still somewhat common in the United States. ${ }^{125}$ And across the globe, there are possibly more polygamous societies than there are monogamous ones. ${ }^{126}$ Most relevant to the current discussion, some American churches endorse the practice as part of their religion, particularly the fundamentalist Latter Day Saints churches. ${ }^{127}$ In addition, one report estimates that anywhere from 50,000 to 100,000

\section{See id. at $4-5$.}

123. I.R.S. Priv. Ltr. Rul. 2013-25-015 (June 21, 2013) (involving a church); IRS Priv. Ltr. Rul. 2013-23-025 (June 7, 2013) (involving a non-church educational and charitable organization). Despite the recent legal victories for same-sex marriage, it seems unlikely that there will be similar victories in the near future for polygamy. See, e.g., John Witte, Jr., Why No Polygamy, in THE CONTESTED PLACE OF RELIGION IN FAMILY LAW 44666 (Robin Fretwell Wilson ed., 2018).

124. See I.R.S. Priv. Ltr. Rul. 2013-25-015, supra note 57; see also I.R.S. Priv. Ltr. Rul. 2013-23-025, supra note 57.

125. See Obergefell, 135 S. Ct. at 2622 (Roberts, C.J., dissenting) (citing Jessica Bennett, Polyamory: The Next Sexual Revolution?, NEWSWEEK (July 28, 2009), https://www.newsweek.com/polyamory-next-sexual-revolution-82053

[https://perma.cc/S9PX-9YTC] (estimating 500,000 polyamorous families in the United States)).

126. Jack B. Harrison, On Marriage and Polygamy, 42 OHIO N.U. L. REv. 89, 94 (2015).

127. See, e.g., Jason D. Berkowitz, Beneath the Veil of Mormonism: Uncovering the Truth About Polygamy in the United States and Canada, 38 U. MIAMI INTER-AM. L. REV. 615, 616 
Muslims currently live in polygamous families in the United States. ${ }^{128}$ So while to date it appears few organizations and even fewer churches have both explicitly supported the practice of polygamy and sought IRS recognition of tax-exempt status - the 2013 denials being an outlier -it is certainly possible that more conflicts over this issue could occur in the future.

In contrast and as mentioned earlier, the IRS appears not to have had a problem with recognizing the tax-exempt status of a church that was candid regarding its intent to incorporate marijuana use into its religious rituals despite the fact that such use was illegal under federal law and under the law of the state where the church was located. ${ }^{129}$ And while this church is not unique, in that there also a number of such churches in California, ${ }^{130}$ it does not appear the IRS is challenging the tax-exempt status of any of them. However, because the IRS does not generally provide explanations for rulings recognizing tax-exempt status or for why it is not choosing to challenge the existing tax-exempt status of an organization, ${ }^{131}$ it is unclear why it is taking this position. And, of course, its position could change if the federal government decides to more aggressively prosecute marijuana offenses.

Some churches might also support or directly engage in activities that violate human rights. For example, some churches, particularly

(2007); see also Eve D'Onofrio, Child Brides, Inegalitarianism, and the Fundamentalist Polygamous Family in the United States, 19 INT'L J.L. POL'Y \& FAM. 373, 375-76 (2005).

128. Barbara Bradley Hagerty, Some Muslims in U.S. Quietly Engage in Polygamy, NPR (May 27, 2008), https:/www.npr.org/templates/story/story.php?storyId=90857818 [https://perma.cc/VE2N-VBLX].

129. See supra note 60 and accompanying text.

130. See Arit John, Inside the War For California's Cannabis Churches, N.Y. TIMES, (Nov. 23, 2019), https://www.nytimes.com/2019/11/23/style/weed-church-california.html [https://nyti.ms/2OAWCLn].

131. See INTERNAL REVENUE SERV., IRS COMPLAINT PROCESS FOR TAX EXEMPT ORGANIZATIONS 2 (2008), https://www.irs.gov/pub/irs-news/fs-08-13.pdf [https://perma.cc/KH9N-YGGB] (noting that the IRS is prohibited from publicly disclosing whether it has initiated an examination or the result of any examination); Terri Lynn Helge, Rejecting Charity: Why the IRS Denies Tax Exemption to 501(c)(3) Applicants, 14 PITT. TAX REV. 1, 2 (2016) (stating that favorable IRS tax exemption determination letters "do[] not set forth the reasons why the organization's application was approved"). 
ones that could be characterized as cults, might actively work to prevent individuals from leaving the church. ${ }^{132}$ Other possible human rights violations could include pressuring spouses to stay in abusive marriages, or, some would argue, putting church members through "gay conversion therapy." 133 The latter is unlikely to constitute the contravention of a fundamental public policy, even though now outlawed in some states, ${ }^{134}$ but certainly allowing individuals to choose their faith is a longstanding human right recognized by the federal government, ${ }^{135}$ and preventing domestic violence has (albeit more recently) also attained that status. ${ }^{136}$ However, in practice, such activities rarely rise to the level of legally actionable coercion and, when they do, likely also involve illegal criminal actions that would provide a clearer basis for loss of taxexempt status if a church directly engaged in such actions. ${ }^{137}$ The IRS therefore might not face a situation where a church has engaged

132. See Cecilia M. Weigel, Note, Trafficking Cults: Why Courts Should Adopt a Broad Reading of the Trafficking Victims Protection Act to Ensure Protection of Cult Victims, 30 GEO. MASON U. C.R. L.J. 269, 272 (2020) ("In some instances, cults force their members to stay within the group.").

133. See, e.g., Robin Fretwell Wilson, The Overlooked Costs of Religious Deference, 64 WASH. \& LEE L. REV. 1363, 1373-77 (2007) (reporting findings that "[r]eligious groups often acquiesce in or, worse, condone family violence within the community"); Susan L. Morrow \& A. Lee Beckstead, Conversion Therapies for Same-Sex Attracted Clients in Religious Conflict: Context, Predisposing Factors, Experiences, and Implications for Therapy, 32 COUNSELING PSYCH. 641, 642 (2004).

134. See Equality Maps: Conversion Therapy Laws, MOVEMENT ADVANCEMENT PROJECT, https://www.lgbtmap.org/equality-maps/conversion_therapy [https://perma.cc/ R6UD-GT2G]; Derrick Bryson Taylor, Colorado Bans "Conversion Therapy" for Minors, N.Y. TIMES, (June 1, 2019) https://www.nytimes.com/2019/06/01/us/gay-conversiontherapy-colorado.html [https://nyti.ms/2EHSbu7] (finding that eighteen states have banned conversion therapy for minors).

135. See UNIVERSAL DECLARATION OF HUMAN RIGHTS, Art. 18 (approved by United States); INT'L COVENANT ON CIVIL \& POLITICAL RIGHTS, Art. 18 (ratified by United States).

136. See Violence Against Women Act of 1994, Pub. L. No. 103-322, tit. IV, 108 Stat. 1902.

137. See Hava Dayan, Modern Day Slavery: A Socio-Legal Analysis of Slavery-Like Offences in Charismatic Cults, 23 BUFF. HUM. RTS. L. REV. 41, 42 n.3 (2016); Weigel, supra note 132, at 274 (asserting that courts in the United States generally do not find psychological coercion alone sufficient to provide the basis for a civil legal claim). 
in such activities in such a way that violates fundamental public policy but does not constitute illegal criminal activity.

Finally, the recent scandals involving various churches and alleged or proven sexual abuse could implicate the Bob Jones University decision but are unlikely to do so. There are few if any claims that the churches in question intentionally endorsed or directed such behavior, and so such behavior should not be attributed to them for tax exemption purposes. This remains the case even though liability might and often has attached to churches arising out of negligence relating to such abuse, under a theory of vicarious liability, or because of intentional efforts to cover up misbehavior that led to further abuse. ${ }^{138}$

In conclusion, there are at least several areas of current or likely future conflict between many churches and fundamental public policy, including sex discrimination in employment, sexual orientation discrimination in employment, sanctuary provision to undocumented immigrants, and polygamy. It is therefore necessary to determine how Bob Jones University should be applied to churches involved in such conflicts.

\section{CHURCHES AND TAXES}

Churches have historically often enjoyed tax exemptions and other tax benefits, as have their leaders. However, the exemptions and other benefits have not always been blanket ones, in large part because of their complicated history and their shifting justifications. ${ }^{139}$ This Part first briefly summarizes the existing tax benefits

138. See, e.g., Stephen M. Bainbridge \& Aaron H. Cole, The Bishop's Alter Ego: Enterprise Liability and the Catholic Priest Sex Abuse Scandal, 46 J. CATH. LEGAL STUD. 65, 68 (2007); Mayo Moran, Cardinal Sins: How the Catholic Sexual Abuse Crisis Changed Private Law, 21 GEO. J. GENDER \& L. 95, 136-41 (2019).

139. See, e.g., NINA J. CRIMM \& LAURENCE H. WINER, POLITICS, TAXES, AND THE PULPIT: PROVOCATIVE FIRST AMENDMENT CONFLICTS 71-72 (2011); DEIRDRE DESSINGUE, The Special Case of Churches, in PROPERTY-TAX EXEMPTION FOR CHARITIES 173, 173-74 (Evelyn Brody ed., 2002). 
for such organizations in the United States and related conditions on them, then considers the constitutional provisions that may either support or conflict with the existence of these benefits, and finally addresses the reasons put forward to support them.

\section{A. Existing Law}

Bob Jones University related to federal tax benefits, so it is appropriate to start there, especially since, for churches, those benefits are more extensive than those enjoyed by non-church religious organizations. ${ }^{40}$ But there are also many tax benefits provided to churches at the state and local level, so this Part briefly discusses those benefits as well.

\section{Federal Tax Law}

Perhaps the most commonly known benefit, which churches share with other types of charities, is exemption from federal income tax under Internal Revenue Code Section 501(c)(3). That provision extends exemption to "[c]orporations, and any community chest, fund, or foundation, organized and operated exclusively for religious, charitable, scientific, testing for public safety, literary, or educational purposes, or to foster national or international amateur sports competition ... or for the prevention of cruelty to children or animals." 141 This exemption is conditional in several ways, beyond the fundamental public policy condition upheld in the Bob Jones University decision. More specifically, Section 501(c)(3) denies exemption to an otherwise qualified organization if it distributes its net earnings to a private party, engages in a substantial amount of lobbying, or supports or opposes any candidate for elected public office. ${ }^{142}$ This exemption is also not unlimited, as it does not extend to "unrelated business taxable income" - oversimplifying, income

140. See Robert H. Wood, Why Churches Are the Gold Standard of Tax-Exempt Organizations, FORBES (Sept. 22, 2015), https://www.forbes.com/sites/robertwood/2015/09/22/lets-tax-churches/?sh=6f1c608b322b [https://perma.cc/VM2SNVL8].

141. I.R.C. $§ 501$ (c)(3) (2018).

142. See id. 
from any regularly carried on trade or business that is not substantially related to the organization's exempt purpose (and does not fall within a statutorily provided exception). ${ }^{143}$ A closely related benefit that is available to almost all Section 501(c)(3) organizations is the ability to receive donations that qualify as deductible charitable contributions for donors; such donations are also generally exempt from federal estate and gift taxes. ${ }^{144}$ Along with other $501(c)(3)$ organizations, churches are also exempt from federal unemployment tax..$^{145}$

Churches enjoy a number of tax benefits generally not enjoyed by other 501(c)(3)s, including exemption from initial application and annual information return requirements and special protections relating to tax inquiries and examinations. ${ }^{146}$ Ministers - that is ordained, commissioned, or licensed religious leaders who usually although not always serve in churches-also enjoy a number of significant tax benefits, including the ability to exclude from their taxable income the value of housing provided to them by a church or cash compensation paid to them to provide housing. ${ }^{147}$

Particularly since some benefits are only available to churches as opposed to all 501(c)(3)s, the IRS has had to determine what qualifies as a "church" for these purposes. The IRS uses a fourteen-factor test, although an organization does not have to satisfy all fourteen factors to qualify. ${ }^{148}$ The courts have used this test and also an "associational test" that considers whether the organization has a

143. See id. $\S \S 511-514$.

144. See id. $\S \S 170(a),(c)(2), 2055$ (a)(2), 2522(a)(2).

145. See id. $\$ 3306(\mathrm{c})(8)$.

146. See id. $\S \S 508(c)(1)(A), 6033(a)(3)(A)(i), 7611$.

147. See $i d$. $\S 107$. This cash compensation aspect of the ministerial housing benefit was recently the subject of an ultimately unsuccessful constitutional challenge. See infra note 180 . Other special tax benefits for churches and ministers relate to retirement plans and payroll taxes. See I.R.C. $\S \S 410(c)(1)(B), 411(e)(1)(B), 412(e)(2)(D), 414(c)(2),(e)$, 1402(a)(8), (e) (2018).

148. See Spiritual Outreach Soc'y v. Comm'r, 927 F.2d 335, 338 (8th Cir. 1991) (citing Remarks of IRS Commissioner Jerome Kurtz, PLI Seventh Biennial Conference on Tax Planning (Jan. 9, 1978), reprinted in Fed. Taxes (P-H) II 54,820 (1978)); I.R.S. Tech. Adv. Mem. 88-33-001 (May 2, 1988); I.R.S. Gen. Couns. Mem. 36,993 (Feb. 3, 1977); INTERNAL 
group of individuals that meets regularly for worship and other religious purposes. ${ }^{149}$ The relative vagueness of both tests is driven in significant part by the need to accommodate "churches" of all faiths or even of arguably none. ${ }^{150}$

\section{State and Local Tax Law}

States and localities of course also impose a variety of taxes, including income, property, and sales and use taxes. In general, most 501(c)(3)s qualify for exemption from these taxes in most states and localities, including almost always churches, although the scope and conditions related to them vary widely. ${ }^{151}$ However and in common with other 501(c)(3)s, churches often do not qualify for exemption from levies that are characterized as user fees or similarly tied to the provision of particular services, such as trash collection. ${ }^{152}$

REVENUE SERV., “CHURCHES” DEFINED, https:/www.irs.gov/charities-non-profits/churches-religious-organizations/churches-defined [https://perma.cc/9EG7-AUQ4]. The IRS first faced the difficult task of determining what constituted a church when Congress initially enacted the unrelated business income tax, which in its original form, exempted churches (and conventions and associations of churches) from this tax. See, e.g., Maggie Flynn, Witchcraft and Tax Exempt Status Under Section 501(c)(3) of the Internal Revenue Code, 21 U.S.F. L. REV. 763, 788 (1987); Schwarz, supra note 43, at 64-67; Wendy Gerzog Shaller, Churches and Their Enviable Tax Status, 51 U. PTTT. L. REV. 345, 350-51 (1990); Bruce Nevin Shortt, The Establishment Clause and Religion-Based Categories: Taking Entanglement Seriously, 10 HASTINGS CONST. L.Q. 145, 166-67 (1982).

149. See Found. of Human Understanding v. United States, 614 F.3d 1383, 1388-89 (Fed. Cir. 2010).

150. See Wash. Ethical Soc'y v. District of Columbia, 249 F.2d 127, 129 (D.C. Cir. 1957); Washington Ethical Society, GUIDESTAR, https:/www.guidestar.org/profile/52-0796318 [https://perma.cc/QEN2-S47C].

151. See Mark J. Cowan, Nonprofits and the Sales and Use Tax, 9 FLA. TAX REV. 1077, 1096 (sales and use tax), 1184-86 (property tax) (2010); John L. Mikesell, State Retail Sales Tax Treatment of Nonprofits, 64 EXEMPT ORG. TAX REV. 37, 41-42, $44-45$ (2009); 50-State Chart of Nonprofit State Tax Exemptions, NONPROFIT STARTUP GUIDE, https://www.harborcompliance.com/information/nonprofit-income-sales-use-tax-exemptions-by-state [https://perma.cc/6ERM-G4EJ].

152. See DAPHNE A. KeNYON \& ADAM H. LANGLEY, THE PROPERTY TAX EXEMPTION FOR NONPROFITS AND REVENUE IMPLICATIONS FOR CITIES 5-6 (2011), https://www.urban.org/research/publication/property-tax-exemption-nonprofits-and-revenue-implications-cities/view/full_report. [https://perma.cc/3DUG-YZGF]. 


\section{B. Constitutional Reasons for Tax Benefits}

The First Amendment of the Constitution of the United States provides: "Congress shall make no law respecting an establishment of religion, or prohibiting the free exercise thereof ...."153 The application of this provision to taxation of churches is far from clear. Both the Free Exercise Clause and the Establishment Clause have been invoked to support exempting churches from taxation and other tax benefits, while the Establishment Clause has also been invoked as a basis for holding such benefits invalid. ${ }^{154}$ This Part considers each clause in turn.

\section{Free Exercise Clause}

The Free Exercise Clause argument is that the taxation of a church's income would place a substantial burden on the exercise of religion both by directly reducing the financial resources of the church and by imposing other costs on the church, including administrative costs and potential chilling effects. ${ }^{155}$ The argument can also be extended to the taxation of funds provided by donors to the church (if such donors are not permitted to deduct their contributions), although it is obviously weaker in that context, and to some if not all of the other tax benefits enjoyed by churches at both the federal and state levels. ${ }^{156}$ The counterargument is that a mere reduction in financial resources that is not targeted at churches but instead is generally applicable to all organizations is not a substantial burden on the exercise of religion, and that even if it were it is more than justified by the revenue needs of the state. ${ }^{157}$

\section{U.S. CONST. amend. I.}

154. See infra notes 170-172 and accompanying text.

155. See, e.g., Schwarz, supra note 43, at 55-56 (summarizing but not endorsing this argument); Christine Roemhildt Moore, Comment, Religious Tax Exemption and the "Charitable Scrutiny" Test, 15 REGENT U. L. REV. 295, 308-09 (2002) (same).

156. See, e.g., J. Michael Martin, Should the Government Be in the Business of Taxing Churches?, 29 REGENT U. L. REV. 309, 321-22 (2017).

157. See, e.g., Evelyn Brody, Legal Theories of Tax Exemption: A Sovereignty Perspective, in PROPERTY-TAX EXEMPTION FOR CHARITIES 145, 160 (Evelyn Brody ed., 2002) [hereinafter Brody, Legal Theories]; Simon, supra note 64, at 505-07; see also Hernandez v. 
Perhaps unsurprisingly, courts have favored the counterargument even though they have not squarely ruled in its favor with respect to churches. ${ }^{158}$ Even before the Supreme Court decided in Employment Division v. Smith ${ }^{159}$ that the Free Exercise Clause does not provide a defense for violations of neutral laws of general applicability, the Court repeatedly denied free exercise claims that sought exemptions from generally applicable taxes. ${ }^{160}$ For example, in United States $v$. Lee, ${ }^{161}$ the Supreme Court refused to exempt an Amish employer from paying Social Security taxes - to which he objected on religious grounds - because of the government's compelling interest in the uniform application of the social security tax system. ${ }^{162}$ And as already noted, the Court in Bob Jones University rejected the claim that the Free Exercise Clause barred the federal government from revoking the tax benefits enjoyed by the religious schools involved. ${ }^{163}$ In addition, attempts by religious organizations to challenge other conditions on tax exemption relating to political activity based on the Free Exercise Clause have failed in federal appellate courts. ${ }^{164}$ The courts have also rejected Free Exercise Clause challenges to other requirements for Section 501(c)(3) tax-exempt status. ${ }^{165}$ The only exceptions appear to be when the tax at issue is

Comm'r, 490 U.S. 680, 699 (1989) (suggesting without deciding that a denial of a charitable contribution deduction for a payment to a church may not place a substantial burden on the free exercise of religion).

158. See, e.g., Dessingue, supra note 139, at 177-78; Moore, supra note 155, at 309-11.

159. 494 U.S. 872 (1990).

160. Id. at 885 .

161. 455 U.S. 252 (1982).

162. Id. at 258-59; see also Jimmy Swaggart Ministries v. Bd. of Equalization, 493 U.S. 378, 392 (1990) (concluding that the Free Exercise Clause does not require a state to grant an exemption to a religious organization from the collection and payment of a generally applicable sales tax); Hernandez, 490 U.S. at 699-700 (citing Lee in rejecting a free exercise challenge to the disallowance of a charitable contribution deduction for certain payments to a church); Thomas, supra note 56, at 612-13 (discussing Lee).

163. See supra Part I.A.

164. E.g., Branch Ministries v. Rossotti, 211 F.3d 137, 142-44 (D.C. Cir. 2000); Christian Echoes Nat'1 Ministry v. United States, 470 F.2d 849, 856-57 (10th Cir. 1972); see also Schwarz, supra note 43, at 73-80 (discussing Christian Echoes Nat'l Ministry).

165. E.g., Parker v. Comm'r, 365 F.2d 792, 795 (8th Cir. 1966); Church of Scientology v. Comm'r, 83 T.C. 381, 458-60 (1984), aff'd 823 F.2d 1310 (9th Cir. 1987). 
effectively a prior restraint on religious activity, ${ }^{166}$ intentionally targets disfavored religious practices, ${ }^{167}$ or is so draconian as to have a prohibitory effect. ${ }^{168}$

The position that the courts have taken with respect to Free Exercise Clause claims relating to taxation is the correct one, regardless of whether that conclusion is reached using the reasoning in Employment Division v. Smith or a strict scrutiny analysis. Even assuming that taxation by itself imposes a substantial burden on religious exercise - which is debatable - the imposition of generally applicable tax laws in a neutral manner to churches is narrowly tailored to further the government's compelling interest in collecting sufficient revenue in an efficient and uniform manner. Merely invoking the famous quotation that "the power to tax involves the power to destroy" is not enough to counter this argument if the tax law at issue is reasonable in amount and generally applicable; as the quoted source goes on to correctly state, "Taxation ... does not necessarily and unavoidably destroy."169

2. Establishment Clause

The Establishment Clause's application is trickier, in part because it can reasonably be invoked to both support and oppose tax benefits for churches. Some commentators argue that since the Establishment Clause prohibits governments not only from favoring particular faiths but also from favoring religion generally over nonreligion, providing tax benefits to religious organizations is unconstitutional. ${ }^{170}$ Some argue instead or in addition that such exemptions raise significant entanglement concerns, including those caused by having to determine what constitutes a "religion" or a

166. See Jimmy Swaggart Ministries, 493 U.S. at 389; Dessingue, supra note 139, at 17778.

167. See Church of the Lukumi Babalu Aye v. Hialeah, 508 U.S. 520, 546 (1993).

168. See Kenneth C. Halcom, Taxing God, 38 MCGEORGE L. REV. 729, 751-52 (2007).

169. McCulloch v. Maryland, 17 U.S. 316, 431 (1819); see also Halcom, supra note 168, at 749 (making this same point).

170. See, e.g., Ellis West, The Case Against a Right to Religion-Based Exemptions, 4 NOTRE DAME J.L. ETHICS \& PUB. POL'Y 591, 600 (1990). 
"church," that render them unconstitutional. ${ }^{171}$ In their view the benefits provided to churches only are even more vulnerable to an Establishment Clause challenge because they are not available to any other tax-exempt nonprofits. ${ }^{172}$

Supporters of the tax benefits for churches have in turn argued that the Establishment Clause requires those benefits because otherwise the government would become excessively entangled in the internal affairs of churches. ${ }^{173}$ Their case is strongest in the income tax exemption context, where determining the taxable income of a church would require difficult decisions on both the income sidefor example, are donations to a church excluded from gross income as "gifts" in all situations, or only when they are not motivated (compelled?) by a perceived religious obligation-and the deduction side-for example, normally only expenses incurred to generate income are deductible, so it is unclear what expenses incurred by a church would be deductible other than fundraising costs and investment fees. ${ }^{174}$ Other tax contexts raise less significant entanglement concerns because, for example, the application of sales and use tax to purchases or sales by a church requires little involvement in the church's internal affairs; while property taxes could raise difficult valuation issues for church buildings, ${ }^{175}$ such taxes again do not require much if any involvement in a church's internal affairs. At the same time, exemptions and other tax benefits are not free from entanglement concerns, in large part because of the need to determine which organizations qualify for the tax benefit at issue.

171. See, e.g., Donna D. Adler, The Internal Revenue Code, the Constitution, and the Courts: The Use of Tax Expenditure Analysis in Judicial Decision Making, 28 WAKE FOREST L. REV. 855, 900-01 (1993); Shortt, supra note 148, at 146, 182, 185. But see Erika King, Tax Exemptions and the Establishment Clause, 49 SYRACUSE L. REV. 971, 1010-14 (1999) (rejecting this argument).

172. See, e.g., Shaller, supra note 148, at 360-61; West, supra note 170, at 610.

173. See, e.g., Reka Potgieter Hoff, The Financial Accountability of Churches for Federal Income Tax Purposes: Establishment or Free Exercise?, 11 VA. TAX REV. 71, 112-13 (1991); Thomas, supra note 56 , at $627-30$.

174. See Boris I. Bittker, Churches, Taxes and the Constitution, 78 YALE L.J. 1285, 12981300 (1969).

175. See John Witte, Jr., Tax Exemption of Church Property: Historical Anomaly or Valid Constitutional Practice?, 64 S. CAL. L. REV. 363, 410 (1991). 
The courts have walked a careful line in this area. In Walz $v$. Tax Commission, ${ }^{176}$ the Supreme Court determined that when a tax benefit is generally available to a broad range of organizations, including but not limited to churches and other religious organizations, and so not intended to advance religion specifically, and also does not have the effect of excessively entangling government with religion, then it is permissible under the Establishment Clause. ${ }^{177}$ While that decision concerned a property tax exemption, commentators and lower courts have generally seen its reasoning as applying in other tax contexts, including income taxes. ${ }^{178}$ At the same time, in one instance when a tax benefit was made available only with respect to a religious activity, the Supreme Court found that the benefit violated the Establishment Clause by favoring religious activity over non-religious activity. ${ }^{179}$ Relying on the latter case, a federal district court recently found the federal income tax exemption for cash payments used for ministerial housing violated the Establishment Clause, although an appellate court reversed that decision. ${ }^{180}$ The plaintiffs did not seek Supreme Court review, ${ }^{181}$ so it is still possible, although unlikely, that the Supreme Court might conclude this tax benefit is unconstitutional in a future case. If that were to occur, there likely would be other successful Establishment Clause challenges to church and minister-specific tax benefits.

Professor Edward Zelinsky has comprehensively considered these Establishment Clause issues in a book-length analysis that we

176. 397 U.S. 664 (1970).

177. Id. at 672-73, 675-76 (1970).

178. See generally King, supra note 171.

179. Texas Monthly v. Bullock, 489 U.S. 1, 14 (1989) (Brennan, J., plurality opinion), 28 (Blackmun, J., concurring).

180. Gaylor v. Mnuchin, 278 F. Supp. 3d 1081, 1090, 1104 (W.D. Wis. 2017), rev'd, 919 F.3d 420 (7th Cir. 2019). In the interests of full disclosure, on appeal one of the authors signed an amicus curiae brief in this case arguing that this tax benefit does not violate the Establishment Clause.

181. Atheists Give up $\$ 1 B$ Church Tax Lawsuit, THE BECKET FUND FOR RELIG. LIB., https://www.becketlaw.org/media/atheists-give-1b-church-tax-lawsuit/

[https://perma.cc/75S7-K85R]. 
will not attempt to replicate in detail here. ${ }^{182}$ Suffice it to say that he is correct that entanglement concerns arise both when generally applicable tax laws apply (which he calls "enforcement entanglement") and when churches are granted exemptions to such laws (which he calls "borderline entanglement") and that therefore the Establishment Clause does not render any such benefits unconstitutional. ${ }^{183}$ While some would go further than Professor Zelinsky and argue that the Establishment Clause requires exemption from at least federal and state income taxes in most situations, ${ }^{184}$ there is little indication that the courts are open to such an argument. ${ }^{185} \mathrm{Un}$ der any conditions, accepting this extension is not necessary for resolving how Bob Jones University should apply to churches. Instead, it is sufficient to conclude that such benefits are constitutionally permissible, as the Supreme Court held with respect to the property tax exemption at issue in Walz. ${ }^{186}$

\section{Policy Reasons for Tax Benefits}

The existence of these many tax benefits naturally raises the question of why churches should receive them if they are not constitutionally required. Governments, academics, and others have provided numerous justifications for these benefits. ${ }^{187}$ Critics of these benefits have also marshalled arguments for why churches should not enjoy them, whether in part or in whole. ${ }^{188}$ This Part considers the historical but no longer applicable reasons, the commonly asserted quid pro quo rationale, and finally an autonomy or "soft sovereignty" approach, which we adopt.

182. See EDWARD A. ZELINSKY, TAXING THE CHURCH: RELIGION, EXEMPTIONS, ENTANGLEMENT, AND THE CONSTITUTION (2017).

183. See id. at xv, xvii.

184. See, e.g., Halcom, supra note 168 , at 756, 760-62, 765-66.

185. See ZELINSKY, supra note 182 , at 23.

186. Walz v. Tax Comm'n, 397 U.S. 664, 680 (1970).

187. See Lloyd Hitoshi Mayer, The "Independent" Sector: Fee-for-Service Charity and the Limits of Autonomy, 65 VAND. L. REV. 49, 64-69 (2012) (summarizing justifications); McCormack, supra note 67, at 984-989 (same).

188. See infra notes 204-206 and accompanying text. 
1. Historical Reasons: Hard Sovereignty or Arm of the State

Churches (and often their leaders) have enjoyed tax exemptions and other tax benefits for thousands of years. ${ }^{189}$ One possible reason for the earliest examples is what could fairly be characterized as a "strong sovereignty" justification-churches and their leaders are not answerable to the state, but to a separate (and powerful) sovereign (whether God or gods), and so should not be subject to tax by the state. ${ }^{190}$ At a more practical level, this justification may be related to the fact that religious institutions and their leaders often constituted a separate source of significant political power that could and would resist, likely successfully and perhaps violently, any attempts by the state to tax them. ${ }^{191}$ However, this justification no longer holds sway either at the theoretical or the practical level in the United States, where the federal and state governments are now the only legally recognized sovereigns ${ }^{192}$ (other than Native American tribes in some respects ${ }^{193}$ ).

A more well documented historical reason for providing tax benefits to some but not all churches is when the state has established a state church. ${ }^{194}$ In that situation, tax benefits are justified because the state church is an arm of the government and so, like government agencies, is not subject to taxation. ${ }^{195}$ In the past this also often

189. See, e.g., CRIMM \& WINER, supra note 139, at 71 n.1; John W. Whitehead, Tax Exemption and Churches: A Historical and Constitutional Analysis, 22 CUMB. L. REV. 521, 522 31 (1991).

190. See, e.g., Halcom, supra note 168 , at $736-37$.

191. See, e.g., King, supra note 191, at 973-75.

192. Halcom, supra note 168 , at 748; Thomas, supra note 56 , at $610-11$. See also MARC O. DEGIROLAMI, THE TRAGEDY OF RELIGIOUS FREEDOM 191-93 (2013) (aspects of religious establishment continued in the United States until at least the 1940s).

193. See COHEN'S HANDBOOK OF FEDERAL INDIAN LAW $\S \S 4.01-4.07$ (2012 ed.).

194. Halcom, supra note 168 , at 737.

195. See, e.g., CRIMM \& WINER, supra note 139, at 75-76; WILLIAM GEORGE TORPEY, JUDICIAL DOCTRINES OF RELIGIOUS RIGHTS IN AMERICA 171 (1948); Halcom, supra note 168, at 737; Witte, supra note 175, at 374-75; Carl Zollman, Tax Exemptions of American Church Property, 14 MiCH. L. REV. 646, 648 (1915); Christine Roemhildt Moore, Note, Religious Tax Exemption and the Charitable Scrutiny Test, 15 REGENT U. L. REV. 295, 29899 (2002). 
meant that churches from other faiths enjoyed only the tax benefits available to charitable entities but not those limited to the established state church, but over time governments have usually extended the tax benefits the state religion historically enjoyed to other faiths. ${ }^{196}$ Often governments may have done so out of a vague idea of fairness or in the face of political pressure without much apparent consideration of why these benefits should extend to private entities that are not arms of the state. ${ }^{197}$ Of course, the United States has never had a national church and the states that did have a state church no longer do, so this arm of the state justification also no longer applies. ${ }^{198}$

\section{Quid Pro Quo}

Given that neither a strong sovereignty nor an arm of the state justification applies in the United States, the most commonly cited modern justification is a quid pro quo one. ${ }^{199}$ Applied not only to churches but to all 501(c)(3)s, this justification is essentially that the societal benefits provided by these organizations, including but not limited to the provision of services that governments would otherwise provide, exceed the societal costs of the tax benefits they enjoy. ${ }^{200}$ More sophisticated versions of this argument include economic theories that assert certain societally beneficial goods and

196. See Witte, supra note 175 , at $379-80$.

197. See id. Indeed, according to Professor John Witte, the disappearance of state churches in the United States led to the first significant criticism of tax exemptions for churches in the 1810 s. Witte, supra note 175 , at 381.

198. See DeGIROLAMI, supra note 192, at 191; King, supra note 191, at 977-78; Shortt, supra note 148, at 161-62; Zollman, supra note 195, at 648-49.

199. See, e.g., EDITH L. FISCH ET AL., CHARITIES AND CHARITABLE FOUNDATIONS 246 (1974); TORPEY, supra note 195, at 172; Zollman, supra note 195, at 64647; Dessingue, supra note 139, at 174-75; Halcom, supra note 168, at 740; King, supra note 191, at 981; Witte, supra note 175 , at 387 . This rationale is not purely modern, however, as it can be traced back to at least the English Statute of Charitable Uses of 1601. See CRIMM \& WINER, supra note 139, at 76-77; Halcom, supra note 168, at 738; Witte, supra note 175 , at 375-76.

200. See, e.g., Schwarz, supra note 43, at 55; Moore, supra note 195, at 296-97; see also Bob Jones Univ. v. United States, 461 U.S. 574, 589-92 (1983) (arguing that charitable exemptions are justified by the public benefit provided by the exempt entity). But see Walz v. Tax Comm'n, 397 U.S. 664, 674 (1970) ("We find it unnecessary to justify the tax 
services would be provided at a suboptimal level absent the support provided to $501(\mathrm{c})(3) \mathrm{s}$ through these tax benefits ${ }^{201}$ and political science theories that emphasize the pluralism benefits created through this support of 501(c)(3)s. ${ }^{202}$ Although a separate set of modern theories relies on "tax base" arguments that the net income (or property, or sales by, or purchases by) of either churches specifically or charities generally is not part of the base of the tax under consideration when properly theorized, these theories are less favored, have acknowledged gaps, and perhaps most importantly, have not had any traction with the courts. ${ }^{203}$

One potential difficulty with this quid pro quo justification as applied to churches is that some commentators contest whether and to what extent churches provide societal benefits, both generally and in specific instances. ${ }^{204}$ The severest critics of tax benefits for churches usually view the societal benefits they provide as minimal or nonexistent, dismissing most churches as no more than social clubs for their members. ${ }^{205}$ While even these critics acknowledge that some churches provide beneficial services, such as soup kitchens or homeless shelters, their view is that these activities could and

exemption on the social welfare services or 'good works' that some churches perform for parishioners and others.").

201. See generally John Simon, Harvey Dale \& Laura Chisolm, The Federal Tax Treatment of Charitable Organizations, in THE NONPROFIT SECTOR: A RESEARCH HANDBOOK 267, 274-75 (Walter W. Powell \& Richard Steinberg eds., 2d ed. 2006).

202. See, e.g., Schwarz, supra note 43, at 56; Terry L. Slye, Rendering Unto Caesar: Defining "Religion" for Purposes of Administering Religious-Based Tax Exemptions, 6 HARV. J.L. \& PUB. POL'Y 219, 249 (1983); Moore, supra note 195, at 297; see also Walz, 397 U.S. at 689 (Brennan, J., concurring) (emphasizing the unique contribution of religious organizations to pluralism).

203. See, e.g., Regan v. Taxation with Representation of Wash., 461 U.S. 540, 544 (1983) (stating that, in case involving whether a nonprofit qualified for tax benefits, "[b]oth tax exemptions and tax deductibility are a form of subsidy"); Bittker, supra note 174, at 1288-92 (applying these tax base theories to churches); Mayer, supra note 187, at 64-65 (summarizing these theories and their flaws); Schwarz, supra note 43, at 56-57 (applying these theories to churches and identifying issues when doing so).

204. See, e.g., Schwarz, supra note 43, at 55.

205. See, e.g., Miranda Fleischer, Churches Are More Private Club than Public Good. Why Do They Need Tax Exemptions?, WASH. POST (Sept. 17, 2015), https://www.washingtonpost.com/news/in-theory/wp/2015/09/17/churches-are-more-club-than-publicgood-why-do-they-need-tax-exemptions/ [https://perma.cc/9MY6-MKZC]. 
should be required to be spun off into separate legal entities to enjoy their justified tax benefits, while stripping those benefits from churches. ${ }^{206}$

Supporters of tax benefits for churches that rely on this justification have a very different view of the effect of churches on society. They argue that churches, at least in the aggregate, provide numerous benefits to society. ${ }^{207}$ These benefits include not only concrete goods and services such as feeding the poor but also more difficult to measure but no less real benefits, such as moral instruction, cultivation of public spiritedness, and fostering of democratic principles. ${ }^{208}$ And these benefits redound not only to individuals involved with churches but society more generally. ${ }^{209}$

\section{Autonomy (or Soft Sovereignty)}

Professor Evelyn Brody has identified, but not endorsed, a "soft sovereignty" approach that may explain in large part the tax exemptions enjoyed by charities, based on the notion that taxation of at least some types of private organizations should be limited out of recognition that there are spheres of society that should be mostly beyond the state's authority. ${ }^{210}$ Focusing on churches specifically, adopting this approach leads to a right of churches to enjoy

206. See, e.g., Mark Oppenheimer, Now's the Time To End Tax Exemptions For Religions Institutions, TIME (June 28, 2015, 11:16 AM), https://time.com/3939143/nows-the-timeto-end-tax-exemptions-for-religious-institutions/ [https://perma.cc/E64K-X3MT]; Editorial, Churches Should Pay Taxes!, THE CHRISTIAN CENTURY, Apr. 9, 1947, reprinted in The Christian Century Reader 327, 328 (Harold E. Fey \& Margaret Frakes eds., 1962).

207. See, e.g., Berg, supra note 16, at 1352-55; Schwarz, supra note 43 , at 56 (summarizing this argument without endorsing it); Witte, supra note 175, at 387-88; Zollman, supra note 195, at 647 (summarizing this argument without endorsing it). For arguments that religion is distinctive and so deserves special legal protection, see generally KATHLEEN A. BRADY, THE DISTINCTIVENESS OF RELIGION IN AMERICAN LAW: RETHINKING RELIGION ClAUSE JURISPRUDENCE (2015); Christopher C. Lund, Religion is Special Enough, 103 VA. L. REV. 481, 493-500 (2017).

208. See, e.g., Berg, supra note 16, at 1352-55; Schwarz, supra note 43 , at 56 (summarizing this argument without endorsing it).

209. Witte, supra note 175 , at 387.

210. Evelyn Brody, Of Sovereignty and Subsidy: Conceptualizing the Charity Tax Exemption, 23 J. CORP. L. 585, 587-89 (1998); Legal Theories at 151-53; see also Mayer, supra note 
autonomy in most situations, including with respect to finances. ${ }^{211}$ Taxing churches risks violating this autonomy because it necessarily requires the state to become involved in the financial affairs of churches, although the extent of that involvement will vary depending on the type of tax and the type of tax benefit involved.

This autonomy or soft sovereignty justification arises from the view that, in any society where the state is not all encompassing, there necessarily are areas that should be free from state oversight and interference. ${ }^{212}$ Churches have a particularly strong argument for being such an area, at least with respect to their internal affairs. ${ }^{213}$ That is because they provide an institutional setting for people who share a faith to practice that faith, to interact in ways designed to promote understanding and promulgation of that faith, and to consider how their faith should affect their lives outside of the church setting. ${ }^{214}$ In other words, it is religiously significant activities that are protected, as Professor Laycock notes. ${ }^{215}$ Any state involvement with the internal affairs of churches risks disrupting these important, private activities, particularly given both the power of the state and the fact that the state's views will almost certainly conflict with at least some of the teachings of most faiths. ${ }^{216}$ Some commentators also find a legal basis for this justification in the Religion Clauses of the First Amendment. ${ }^{217}$ The next

203, at 70-71 (proposing an autonomy perspective for evaluating the legal rules relating to charities).

211. E.g., Brunson \& Herzig, supra note 33, at 1202-03; Martin, supra note 156, at 309; see also IRA C. LUPU \& ROBERT W. TUTTLE, SECULAR GOVERNMENT, RELIGIOUS PEOPLE 43-44 (2014) (describing the broader debate over church autonomy).

212. See Brody, supra note 210 , at 588 .

213. Douglas Laycock, Church Autonomy Revisited, 7 GEO. J.L. \& PUB. POL'Y 253, 267 (2009).

214. See Lund, supra note 207 , at $490-91$.

215. Laycock, supra note 213, at 267-68; see also DEAN M. KELLEY, WHY CHURCHES SHOULD NOT PAY TAXES 41 (1977) (characterizing churches as "the central repositories of religious activity, from which may flow many kinds of partial or peripheral religious interests or ministrations").

216. See, e.g., Berg, supra note 16, at 1341-43.

217. See Richard W. Garnett, Why churches shouldn't have to pay taxes, U.S. CATHOLIC (Oct. 24, 2016), https://www.uscatholic.org/articles/201610/why-churches-shouldnthave-pay-taxes-30799 [https://perma.cc/XHQ8-47FQ]; supra Part III.B. 
Part therefore focuses on this approach, exploring the philosophical and legal bases for it.

\section{WHY THE INSTTTUTIONAL CONTEXT SHOULD CONTROL}

The idea that the First Amendment-Religion Clauses included-protects institutions as well as individuals has gained steam in recent years. ${ }^{218}$ In regard to churches specifically, the "soft sovereignty" approach described above lines up nicely with the idea that churches, as First Amendment institutions, should be afforded autonomy regarding their internal doctrines and practices. Under the First Amendment institutions theory, churches and other institutions that participate in activities like speech and religion should be afforded First Amendment protections as institutions. This Part first provides a more in-depth treatment of the soft sovereignty approach in light of the philosophical idea of "sphere sovereignty" and then unites it with the legal idea of First Amendment institutions and applies that understanding in the context of tax benefits. This Part concludes by distinguishing and defining churches-both as a theoretical underpinning and legal necessity.

\section{A. Sphere Sovereignty}

\section{The Theory}

The soft sovereignty approach is illuminated by the work of the nineteenth-century neo-Calvinist writer and former Prime Minister of the Netherlands Abraham Kuyper. Kuyper proposed that church and state interact and coexist with each other according to his theory of sphere sovereignty. ${ }^{219}$ Spheres are social institutions in which "authority structures specific to those spheres emerge." 220 Sovereignty is the idea that spheres have a natural right to form both the 
sphere itself and the authority structure that governs it. ${ }^{221}$ Thus, sphere sovereignty is the idea that certain social institutions should enjoy a degree of autonomy within their own domains.

First, we must break down Kuyper's conception of a "sphere." For Kuyper, the four main spheres are the State, Society, the Church, and the Individual. ${ }^{222}$ This Article focuses primarily on the first three. Within society are social spheres, which encompass all aspects of life and include "the family, the business, science, art and so forth." 223 Thus, in this respect, a church can be thought of as a social sphere, though there are important distinctions between the two. ${ }^{224}$ Kuyper describes the sphere-forming process for non-state spheres as "organic." 225 People arrange themselves based on shared interests or localities pursuant to natural forces of human nature..$^{226}$ Such arrangements are "natural" because forming them does not require approval by a church, the state, or any other social sphere. ${ }^{227}$ The state, conversely, is of a "mechanical" nature. ${ }^{228}$ Unlike social spheres, which are formed in a bottom-up fashion, states operate from top-down. ${ }^{229}$ Whereas daily activities occupy the spaces of social spheres, the state qua sphere is a "means of compelling order and of guaranteeing a safe course of life." 230 Put simply, the state is the "sphere of spheres, which encircles the whole extent of human life." 231 The authority and responsibility inherent to each kind of sphere-social versus state-flow from these differences. ${ }^{232}$

221. Id.; see also ABRAHAM KUYPER, CALVINISM: SIX LECTURES DELIVERED IN THE THEOlOGiCAl SEMINARY AT PRINCETON 121 (New York, Revell 1899) ("And in both these spheres[, social and state,] the inherent authority is sovereign, that is to say, it has above itself nothing but God.").

222. KUYPER, supra note 221 , at $99,139$.

223. Id. at 116 .

224. See infra Part IV.C.1.

225. KUYPER, supra note 221, at 115.

226. Id. at 116-17.

227. Id. at 110 .

228. Id. at $116-17$.

229. Id. at 115 .

230. Id. at 101 .

231. ABRAHAM KUYPER, Sphere Sovereignty, in ABRAHAM KUYPER: A CENTENNIAL READER 461, 472 (James D. Bratt ed., 1998).

232. See Wolterstorff, supra note 219 , at 109-10. 
Second, we must understand what Kuyper meant by "sovereignty." In the organic development of social spheres, authority structures emerge by which someone "either in his own person or acting in the name of the institution ... issue[s] directives to others that place those others under the (prima facie) obligation to obey." 233 Each sphere thus develops an authority structure specific to its needs. ${ }^{234}$ Besides the state itself, ${ }^{235}$ spheres do not derive their internal authority from anything or anyone outside of themselves, but it is, rather, "original to them." ${ }^{236}$ And importantly, this inherent ability of a sphere to define the parameters of its internal authority - that is, its "sovereignty" - is not only a descriptive account but a normative one: social spheres have a natural right to organize and to govern themselves. ${ }^{237}$ These concepts are not unique to Kuyper; for example, Professor Victor Muñiz-Fraticelli's conception of sovereignty provides an independent source of legitimacy for institutions based on the concurrence of their members and allows institutions to pursue their collective values without first obtaining permission from another authority. ${ }^{238}$

Kuyper's approach to sovereignty also requires consideration of the authority a sphere-be it a social sphere or the state-has over other spheres. Because a sphere's sovereignty is natural to it, each institution represents a "truly sovereign sphere[], which may not lightly be interfered with by any other sovereign." ${ }^{239}$ Kuyper's focus on autonomy is not only a recognition that spheres are free to organize self-governing structures, but also that they are free from outside interference in their development and self-determination. ${ }^{240}$

233. Id. at 109.

234. Id at 109-10.

235. See KUYPER, supra note 231, at 110-16 (positing that states derive their political authority not from the consent of the governed but from the grace of God).

236. Wolterstorff, supra note 219 , at 110.

237. Id.; see also KUYPER, supra note 221.

238. Victor MUÑIZ-FraticElli, THE STRUCTURE OF PlURALISM 101-17 (2014).

239. Paul Horwitz, Churches as First Amendment Institutions: Of Sovereignty and Spheres, 44 HARV. C.R.-C.L. L. REV. 79, 96 (2009) (emphasis omitted).

240. See Wolterstorff, supra note 219, at 112 ("Kuyper thought that in a modern wellfunctioning society, the authority of an organization should be limited to activities within one particular sphere.... For when an institution comes under the control of 
Unlike social spheres, which must abide by this "principle of noninterference," the state has a unique role to play as the sphere of spheres. ${ }^{241}$ Negatively, the state "may never become an octopus, which stifles the whole of life" but must "honour and maintain every form of life, which grows independently, in its own sacred autonomy." 242 But Kuyper also envisioned a positive role for the state. The state has the:

right and duty: 1 . Whenever different spheres clash, to compel mutual regard for the boundary-lines of each; 2 . To defend individuals and the weak ones, in those spheres, against the abuse of power of the rest; and 3 . To coerce all together to bear personal and financial burdens for the maintenance of the natural unity of the State. ${ }^{243}$

When it governs within these guidelines, the state acts in accord with - but does not exceed the scope of -its sphere sovereignty. ${ }^{244}$ But when the state uses its coercive power to control social spheres without their invitation-be it through restrictive regulations or unequal treatment of similarly situated social spheres - the state exceeds the scope of its sphere sovereignty. ${ }^{245}$

Kuyper envisioned a different role for the social sphere most relevant here: the church. Kuyper taught that, consistent with his theory, no single church should dominate, and, like the state, churches cannot intrude outside of their own spheres. ${ }^{246}$ The latter point implies not only that churches "must stay within their own province," but that a church cannot compel membership of persons who

an institution whose guiding function lies in another sphere, activity within the former institution is almost always distorted by this 'outside' control."). See generally Richard W. Garnett, The Worms and the Octopus: Religious Freedom, Pluralism, and Conservatism, in AMERICAN CONSERVATISM: NOMOS LVI 160 (Sanford V. Levinson et al. eds., 2016) (developing this idea).

241. See Wolterstorff, supra note 219 , at 114.

242. KUYPER, supra note 221, at 124.

243. Id. at 124-25.

244. Id.

245. Id.

246. Horwitz, supra note 239, at 97. 
would voluntarily disassociate with said church. ${ }^{247}$ Positively, a strong church sphere in society acts as a "fundamental limit on state-aggrandizement." ${ }^{248}$ Because churches recognize that their autonomy is ultimately given by God, they are distinguished from other social spheres and, due to their unique metaphysical perspective, are particularly important for the organic development of a thriving, pluralist society. ${ }^{249}$

The church-state relationship that Kuyper imagined grows out of the autonomy inherent to each sphere as well as the respective role that each is to play. Describing Kuyper's theory as creating a society of "guided and divided pluralism," one scholar wrote:

It is guided in that each sphere has 'its own unique set of functions and norms,' and all of them are expressions of God's ultimate sovereignty. It is divided in that each sphere, provided that it acts appropriately, is to remain sovereign, untouchable by church, state, or other social institutions. ${ }^{250}$

In sum, sphere sovereignty respects the inherent autonomy of privately and independently organized peoples-that is, social spheres. The state, itself a sphere, is tasked with ensuring that organically created spheres, including churches, continue to have opportunities to emerge and to flourish. The relationship between church and state under the sphere sovereignty approach thus provides a helpful starting point by which to approach church-state disputes. Moreover, Kuyper's theory, with its skepticism of outside 
interference, fits with an American society in which liberty is regarded as a most cherished right. ${ }^{251}$ It also resonates with the Catholic principle of subsidiarity. ${ }^{252}$

Prior to discussion of the implications of the sphere sovereignty approach for the special tax treatment of churches, we must address the following objection: For the non-Christian, does it matter that Kuyper was not only a devout Calvinist but that his theory of the social structure is explicitly based on Christian ideas? In his application of Kuyper's work to First Amendment institutions, ${ }^{253}$ Professor Paul Horwitz squarely addresses this concern, and his replies are also relevant in employing sphere sovereignty as a justification for the tax benefits received by churches. Kuyper's theory, while unabashedly Calvinist, need not be tied to Calvinism or any religious belief system to retain its coherence and internal consistency. ${ }^{254}$ In fact, scholars who endorse sphere sovereignty have argued that sphere sovereignty, even set loose from its Calvinist roots, "has much to offer to contemporary discussions of civil society." 255 For Professor Horwitz, this modernization of sphere sovereignty also quells concerns regarding the opposite objection-that

251. See The DECLARATION OF INDEPENDENCE para. 2 (U.S. 1776) ("We hold these truths to be self-evident, that all men are created equal, that they are endowed by their Creator with certain unalienable Rights, that among these are Life, Liberty and the pursuit of Happiness."); Charles L. Cohen, The "Liberty or Death" Speech: A Note on Religion and Revolutionary Rhetoric, 38 WM. \& MARY Q. 702 (1981) (giving an historical account of Patrick Henry's famous "Give me liberty, or give me death!" speech); see also Charles Glenn, CPJ's 2017 Kuyper Lecture, Rediscovering Sphere Sovereignty In The Age of Trump (Apr. 27, 2017), https://www.cpjustice.org/public/page/content/2017_kuyper_lecture_remarks [https://perma.cc/PNX2-CFM7].

252. See Robert F. Cochran, Jr., Catholic and Evangelical Supreme Court Justices: $A$ Theological Analysis, 4 U. ST. THOMAS L.J. 296, 304-06 (2006); Horwitz, supra note 239, at 105; PONTIFICAL COUNCIL FOR JUSTICE AND PEACE, COMPENDIUM OF THE SOCIAL DOCTRINE OF THE CHURCH III 185-88 (2004), http://www.vatican.va/roman_curia/pontifical_councils/justpeace/documents/rc_pc_justpeace_doc_20060526_compendio-dottsoc_en.html [https://perma.cc/V6CP-VWGQ] (the principle of subsidiarity).

253. Horwitz, supra note 239 , at $91-99$.

254. See id. at 93-94.

255. Richard J. Mouw, Culture, Church, and Civil Society: Kuyper for a New Century, 28 PRINCETON SEMINARY BULL. 48, 55 (2007); see also Horwitz, supra note 239, at 93-94; 
to separate sphere sovereignty from Calvinism robs the theory of its force. ${ }^{256}$ Rather than break down each aspect of Kuyper's theory and test its secular strength, this Article simply does not rely upon those aspects of sphere sovereignty that are uniquely Calvinist (and has not thus far). Thus, sphere sovereignty remains a helpful theoretical framework for thinking about the relationship between church and state in a modern, pluralist society. ${ }^{257}$

However, because Kuyper is not king, the interplay between his theory and the effects that it has had on American legal thought are useful considerations before applying his metaphor in the modern tax benefits context. ${ }^{258}$ Some of the Founders-Thomas Jefferson, John Adams, and James Madison among them-were influenced by the early settlers' Puritan views on the roles of the state and churches within society, views that parallel Kuyper's later work. ${ }^{259}$ The Calvinist doctrine of covenant gave rise to the Puritan belief that church and state were "two separate covenantal associations, two coordinate seats of godly authority and power in society."260 Inspired by this Puritan-influenced approach to pluralism, in his drafting of the Massachusetts Constitution of 1780, John Adams "guaranteed churches the right to select their own ministers without state interference, a right that is consistent with the concept of

Johan D. Van der Vyver, Sphere Sovereignty of Religious Institutions: A Contemporary Calvinistic Theory Of Church-State Relations, in CHURCH AUTONOMY: A COMPARATIVE SURVEY (Gerhard Robbers ed., 2001).

256. Horwitz, supra note 239, at 93-94. See generally Mark Tushnet, Distinctively Christian Perspectives on Legal Thought?, $101 \mathrm{MICH}$. L. REV. 1858 (2003) (reviewing CHRISTIAN PERSPECTIVES ON LEGAL THOUGHT (2001)) (discussing in general the application of "Christian" ideas to secular legal debates). But see George Harinck, A Historian's Comment on the Use of Abraham Kuyper's Idea of Sphere Sovereignty, 5 J. MARKETS \& MORALITY 277 (2002) (arguing that sphere sovereignty is a credo that cannot be separated from its religious roots).

257. See Horwitz, supra note 239, at 93-94.

258. For a deeper discussion of the effects of sphere sovereignty on the American constitutional structure, see generally PAUL HORWITZ, FIRST AMENDMENT INSTITUTIONS 179-82 (2013).

259. Horwitz, supra note 239 at $100-01$.

260. JOHN WITTE, JR., THE REFORMATION OF RIGHTS: LAW, RELIGION, AND HUMAN RIGHTS IN EARLY MODERN CALVINISM 309 (2007). 
sphere sovereignty."261 The early constitutions of Connecticut, Maine, and New Hampshire had similar provisions. ${ }^{262}$

Moreover, Professor Philip Hamburger observes that even late eighteenth-century Americans who supported religious exemptions would not have argued for a constitutional right to exemptions because, at the time, "the jurisdiction of civil government and the authority of religion were frequently considered distinguishable." ${ }^{263}$ No exemptions were necessary since "Congress shall make no law"264 infringing upon the free exercise of religion, which "assumes Congress can avoid enacting laws that prohibit free exercise" in the first place. ${ }^{265}$ Likewise, Alexis de Tocqueville's description of the nineteenth-century interaction between church and state in America was one that tracks the normative account later proffered by Kuyper. ${ }^{266}$ Professor Horwitz notes that "Tocqueville saw evidence in nineteenth-century America that the Calvinist Puritan ideal had taken root: in Kuyper's words, America had embraced a pluralistic system whose watchword was ' [a] free Church in a free State.'"'267 These historical examples, as well as later philosophical trends that likewise track sphere sovereignty, lead Professor Horwitz to conclude that there is at least "the possibility that the ideas underlying sphere sovereignty are not alien but immanent in the American social and constitutional order."268 As such, Professor Horwitz concludes that real consideration ought to be given to "how sphere sovereignty might be said to shape that order" and how it might affect First Amendment issues. ${ }^{269}$

We do not mean to overstate the influence that Kuyper's theory of sphere sovereignty had on the American Founding, nor do we

261. Horwitz, supra note 239, at 102.

262. See id.

263. Philip A. Hamburger, A Constitutional Right of Religious Exemption: An Historical Perspective, 60 GEO. WASH. L. REV. 915, 936-37 (1992).

264. U.S. CONST. amend. I.

265. Hamburger, supra note 263 , at 938.

266. Horwitz, supra note 239, at 103.

267. Id. at 103 (quoting KUYPER, supra note 221, at 128).

268. Id. at 107.

269. Id. 
mean to claim that it has extensive ongoing political influence. Indeed, Professor Horwitz makes a humble claim: it is possible that sphere-sovereignty-inspired thought influenced developments in American religious liberty law. ${ }^{270}$ Regardless, sphere sovereignty as both a descriptive and normative concept is a useful tool for thinking about current and future First Amendment conflicts and provides at least a framework for explaining and justifying the unique place in society that churches occupy. At its simplest, sphere sovereignty is a way of illustrating the idea that churches "should generally be treated as sovereign, or autonomous, within their individual spheres [and should] coexist alongside the state ... serving a vital role in furthering self-fulfillment, the development of a religious community, and the development of public discourse." 271 Sphere sovereignty therefore paints a specific picture and fills in some of the philosophical gaps as to how such a pluralistic society ought to operate. This Part, while it treats sphere sovereignty as a serious theory, recognizes that it is not constitutionalized by the First Amendment but serves as a theoretical framework for illustrating the relationship between church and state in America so as to further explain the tax benefits that churches receive.

\section{Possible Objections}

Some scholars nonetheless reject the use of this sphere sovereignty approach to justify the (legal) autonomy of churches. In one of the more extensive critiques of church autonomy and religious institutionalism, Professors Richard Schragger and Micah Schwartzman make essentially four claims: (1) that the historical account of religious liberty that supports church autonomy is inaccurate; (2) that church autonomy is anti-republican; (3) that church autonomy justifications have no limiting principles; and (4) that churches cannot be distinguished from secular groups. ${ }^{272}$ As this Part details, their anti-republican and lack of limiting principles

272. Richard Schragger \& Micah Schwartzman, Against Religious Institutionalism, 99 VA. L. REV. 917, 932 (2013). 
charges are unpersuasive on their own terms. We will address their church non-distinguishability argument in a later Part. ${ }^{273}$ Finally, their historical argument is largely levied against those who defend modern-day church autonomy based on certain eleventh century church-state events, ${ }^{274}$ which we do not rely on.

Professors Schragger and Schwartzman argue that church sovereignty is anti-republican because "[i]nstitutions that purport to play a special or outsized role in society should be democratically accountable. The exercise of public power, of territoriality, of jurisdiction, demands democracy." 275 And because churches are not democratically accountable, they have instead justified exercises of sovereignty by expanding Thomas Paine's "church of one" in an attempt to "infuse the institutional church with all the moral authority and independence of the autonomous self." 276 Churches must therefore justify their authority in terms of conscience, not sovereignty, because "mediating institutions no longer exercise government power ... [which is] a product of republican political theory." 277

They also make a related argument that the public-private distinction upon which sphere theorists rely is untenable for churches to support in light of their inability to distinguish themselves from non-religious private institutions. ${ }^{278}$ Where the liberal distinction between state and individual collapses as churches are afforded sovereignty, which, in their view, is ultimately founded upon the individual right of conscience, the public-private distinction must be replaced with something else to maintain the view that churches occupy a unique sphere of sovereignty. Thus, they argue, churches fall back on the church-state distinction-but "determining what is a church is no more tractable than determining what is a religion,

273. See infra Part IV.C. For an institutional critique of Professors Schragger and Schwartzman's article, see Paul Horwitz, Defending (Religious) Institutionalism, 99 VA.

L. REV. 1049 (2013).

274. Schragger \& Schwartzman, supra note 272 , at $933-37$.

275. Id. at 944 .

276. Id. at 943 .

277. Id.

278. Id. at 944 . 
or what is private and what is public."279 Because this argument largely bleeds into their critique of the indistinguishability of churches from secular groups, we address it in our later Part on that issue. ${ }^{280}$

Government power is distinct from sovereignty, however, and no church situated within an otherwise democratic society would have a valid claim to exercising the government's power. Church autonomy stands for the proposition that - within its own spherethe church may exercise sovereign control. Insofar as "[r]epublicanism demands that the people ... constitute the sovereign,"281 some churches are not republican - but such churches would not claim to be so in the first place. The sovereignty of many churches is understood not to derive from the people but from a higher power. Professors Schragger and Schwartzman further argue that republicanism "does not tolerate corporate entities[, including churches,] that operate outside of and in defiance of the state." ${ }^{282}$ As a matter of liberal political theory, this assertion is far from settled. ${ }^{283}$ But even accepting the proposition as true, if "defiance of the state" means violating - to borrow a constitutional term - a "neutral law of general applicability," 284 then the soft sovereignty approach we advance here accommodates that restriction insofar as the law is criminal in nature. 285 The government is without authority, however, to act beyond its own laws - that is, to exceed its sovereign sphere-in controlling the beliefs or practices of churches.

279. Schragger \& Schwartzman, supra note 272 , at 944 .

280. See infra Part IV.C.

281. Schragger \& Schwartzman, supra note 272, at 943.

282. Id.

283. See JOHN RAWLS, THE LAW OF PEOPLES 63 (1999) (arguing that liberal, democratic societies must treat as equals "decent hierarchical peoples," that is, nondemocratic societies that respect basic human rights, even if its members are not guaranteed freedom and equality).

284. Employment Div. v. Smith, 494 U.S. 872, 879 (1990) (quoting United States v. Lee, 455 U.S. 252, 263, n.3 (1982) (Stevens, J., concurring in judgment)).

285. See infra Part V.C. 
Moreover, if Professors Schragger and Schwartzman mean to suggest that churches themselves ought to abide by a democratically elected hierarchy to garner secular approval, that position seems to run counter to their central claim that individual "rights of conscience are doing all the relevant [legal] work." ${ }^{286}$ Democracy is valued not simply because it is politically desirable but because that political desirability necessarily stems from the robust protection of individual liberties that democracies champion, rights of conscience and association chief among them. If members of a democratic society wish to arrange their religious institutions in a patently undemocratic manner, what right does a democratic government have to interfere with this conscious choice? This argument would also prove too much: if churches cannot arrange their affairs in an undemocratic manner, and if, as Professors Schragger and Schwartzman contend, churches are indistinguishable from secular groups, could any groups within a democracy be undemocratically structured? It would seem that universities, privately held corporations, and, taken to its logical extreme, the nuclear family, would potentially be disallowed under their expansive distrust of undemocratic institutions.

But the fear of vast, undemocratically accountable exercises of church sovereignty is further quelled in light of responses to their jurisdictional critique. Professors Schragger and Schwartzman are principally worried about the scope of a church's sphere sovereignty. They ask, "What is the appropriate sphere of church sovereignty if the mission of the church is to save mankind? ... The strong form of sphere sovereignty claims that churches have a special, unique, and exclusive mission to preach the Word, to convert the unconverted, and to glorify God." ${ }^{287}$ Kuyper would likely agree with this classification. ${ }^{288}$ So are there limiting principles?

We wish here to reemphasize our original claim: that church autonomy is justified under a soft sovereignty approach. While 
Kuyper would have rejected the "hard sovereignty" approach, 289 his "strong form of sphere sovereignty" risks a potentially overbroad application, as Professors Schragger and Schwartzman suggest. ${ }^{290}$ But limiting the scope of the church's "sphere" - at least as an abstract matter-is possible, and we recognize that it's a practical necessity if church autonomy is to be legally recognized. ${ }^{291}$

Even under Kuyper's theory, the church is not all-encompassing; the state, not the church, is the sphere of spheres. Thus, while escaping state membership is impossible, the state actually plays an important role in ensuring that, within its jurisdiction, those who wish to join a church may do so, and those who wish to leave a church may also do so. ${ }^{292}$ This understanding comports with Kuyper's posited "sovereignty of the individual person." ${ }^{293}$ Indeed, the state's "right and duty ... [t] defend individuals and the weak ones, in those spheres, against the abuse of power of the rest"294 would be hollow if it could not cabin the church's exercise of its sphere sovereignty to governing its members.

Professors Schragger and Schwartzman respond that "because the institution of the church is the church for all, and because saving souls is central to its mission, the church's jurisdiction can and must be extended to all... [Indeed], Christianity and Islam are explicit about their claims to universality." ${ }^{295}$ But this critique misses the point. Just because some churches believe they have sovereign jurisdiction over all of mankind does not confer to them such jurisdiction given the state's dictates under the sphere sovereignty approach. A Christian may try to convert nonbelievers to the faith, but until the nonbeliever himself chooses Christianity, no Christian church may claim sovereign authority over him. ${ }^{296}$ Kuyper thought

289. See id.

290. Schragger \& Schwartzman, supra note 272, at 946.

291. See infra Part V.C.

292. See supra notes $246-47$ and accompanying text.

293. KUYPER, supra note 221, at 139.

294. Id. at 124 .

295. Schragger \& Schwartzman, supra note 272, at 947.

296. See id. at 957-62. 
that all nations should be Christian. ${ }^{297}$ But even he understood that worldwide Christian rule could "never be realized except through the subjective convictions of those in authority, according to their personal views of the demands of that Christian principle." ${ }^{298}$ If leaders of nation states were not rightfully subjected to the jurisdiction of the church until they themselves converted, it must be true that laymen are afforded this same personal autonomy of choice, with the state serving as the enforcer of the various spheres' boundaries. Therefore, it is possible to limit a church's grandiose exercise of its sovereignty to its own sphere.

Nothing in the preceding paragraphs should be taken to suggest that churches must forfeit their right to persuade others to join their faith in the public square. Just as secular social spheres may try to increase their membership, so too may churches. The preceding discussion stands for the principle that unless and until a person decides to join a church, that church has no sovereign authority over that person because that person is rightfully outside of the church's sphere and thus its sovereign control. A church's conception of what constitutes its sphere-for example, the Christian belief that all human persons are children of $\mathrm{God}^{299}$ - and the exercise of sovereignty within that sphere may not always line up. Such differences are reconcilable given a state that, "[w]henever different spheres clash[,] ... compel[s] mutual regard for the boundary-lines of each." 300

Thus, we agree with Professors Schragger and Schwartzman that voluntary church membership is a necessary condition for churches to exercise authority under our soft sovereignty approach. ${ }^{301}$ That certain religions might not view membership as voluntary has no bearing on how the state must treat those churches.

297. KUYPER, supra note 221, at 135.

298. Id.

299. Cf. Schragger \& Schwartzman, supra note 272, at 946 ("[C]hurches often assert that their jurisdiction extends to non-members of the institution. Indeed, it may be a central doctrine of the church that it alone appropriately rules in all spiritual and temporal matters regardless of membership.").

300. KUYPER, supra note 221, at 124.

301. See Schragger \& Schwartzman, supra note 272, at 957. 
If a member in such a church cannot leave even though she wishes to, the state has the rightful power-and in fact, duty - to ensure the free flow of members between social spheres. ${ }^{302}$ We further agree that this voluntarism disallows the state from "assisting in coercing non-members while requiring the state to enforce exit rights, ${ }^{\prime 303}$ but we disagree that voluntary church membership necessitates church autonomy based on conscience or associational rights, as opposed to religious freedom. The soft sovereignty framework allows for sovereignty-based autonomy wherein sphere members may join and leave sovereign spheres as they please. We acknowledge that separating from a church is not always easy given the "coercive" doctrines of certain churches and other internal pressures to stay. ${ }^{304}$ The potential costs of leaving do not undermine that the choice of leaving is voluntary (or is at least viewed as such by the government) in the first place. As long as it is possible to leave-so ensured by the state's obligation and duty to protect against abuses of sovereign power - the necessary condition of voluntary church membership is satisfied. ${ }^{305}$ Soft sovereignty is compatible with and is in fact premised upon voluntarism (which is also consistent with Kuyper's treatment of individuals as another separate sphere). ${ }^{306}$

3. Sphere Sovereignty, Churches, and Tax Benefits

The tax exemption and charitable contribution deduction enjoyed by churches are justified in light of the above sphere sovereignty framework. The United States, along with state and local governments, constitutes the sphere of spheres as the state, while churches are one of a plethora of social spheres within Américan society. ${ }^{307}$ Both the United States and churches are spheres, so each must

302. See supra notes 239-243 and accompanying text.

303. Schragger \& Schwartzman, supra note 272, at 960.

304. See KUYPER, supra note 221, at 141-42.

305. See Schrager \& Schwartzman, supra note 272, at 960.

306. See KUYPER, supra note 221, at 127 ("[T] he struggle for liberty is not only declared permissible, but is made a duty for each individual in his own sphere.").

307. But see infra Part IV.C. (distinguishing churches). 
abide by the principle of noninterference essential to Kuyper's approach. ${ }^{308}$ Recall that the state has three affirmative duties, the first two of which require the state to keep peace among spheres and to defend individuals within spheres "against the abuse of power," respectively. ${ }^{309}$ It is from the third, "to coerce all together to bear personal and financial burdens for the maintenance of the natural unity of the State," that the state derives its legitimate power to levy taxes. ${ }^{310}$ But this power is checked by the first two duties in conformity with the principle of noninterference. ${ }^{311}$ All spheres have the natural right to exercise the inherent sovereignty "original to them. ${ }^{\prime 312}$ The argument we advance herein, based on the soft sovereignty theory articulated above, provides a philosophical basis upon which the special tax treatment of churches can be explained in light of Bob Jones University. We later offer a number of practical, necessary line-drawing limitations to curb overzealous application of the soft sovereignty approach in this context. ${ }^{313}$

First, the tax exemption. As sphere of spheres, the United States has an obligation to respect the inherent sovereignty of churches. The state does this most obviously by affording churches the autonomy to manage their own property. ${ }^{314}$ Any taxation levied upon any entity necessarily entangles that entity with the state. When the state does not tax an entity, it reduces entanglement, increasing the autonomy afforded to that entity. Because churches are to be autonomous within their own spheres, the state ought not tax churches because in so doing, it allows churches the fullest control over their resources. Churches, as soft sovereigns, ought to be afforded the autonomy to enjoy complete control over the allocation of their property - money and otherwise-without the outside influence of the state interfering with that control. Taxes necessarily infringe upon this right. Therefore, if the state and churches truly are soft

308. See supra notes $240-242$ and accompanying text.

309. See supra note 243 and accompanying text.

310. KUYPER, supra note 221, at 124-25 (emphasis omitted).

311. Id. at 125.

312. Wolterstorff, supra note 219 , at 110.

313. See infra Part V.C.

314. See supra Part III.C.3. 
sovereigns within the sphere sovereignty framework, taxing churches violates the autonomy inherent to them. Refraining from taxing churches is also consistent with the state's duty to adhere to the principle of noninterference. So while tax exemption is not necessarily constitutionally required for the reasons previously discussed, it is desirable as a policy matter. In addition, once tax exemption is granted, this soft sovereignty approach argues against taking away that benefit for violating fundamental public policy.

Second, the charitable contribution deduction is also justified in light of the sphere sovereignty approach. The United States respects the sovereignty of churches by allowing them to manage their own property. ${ }^{315}$ It follows that the United States must afford church members this same autonomy, at least with respect to the church members' property that is charitably given to a church. To comply with the principle of noninterference in its treatment of churches, while at the same time not extending similar treatment to church members, is a contradiction in terms: What is a church-and more broadly, a sphere - if not a collection of members? Respecting the autonomy of churches to manage their property thus necessitates the charitable contribution deduction. A church member may rightly contend that his annual gift to his church is not first "his" money that upon his donation becomes "the church's." Rather, the donated money always belonged to the church. The member is merely the medium by which that money is transferred from one sphere, call it "the market," 316 to another, namely, "the church." Once there, as was shown above, that money is rightfully free from taxation. But for the charitable contribution deduction, property that belongs to churches would, in effect, be taxed via the increased tax base to which church members would be susceptible, increasing their taxes owed to the state. ${ }^{317}$ Consequently, churches would not

316. Of course, money that remains in the sphere we have labeled "the market," which ought to be defined extremely broadly, is susceptible to taxation under the third duty of state spheres. See supra note 310 and accompanying text.

317. This "tax base" argument differs from those disfavored in the text accompanying supra note 203. Above, the "tax base" in question is the church's income itself. But 
be afforded the sovereignty inherent to them but would instead be subjugated to the coercive power of the state in contradiction of the principle of noninterference. Of course, not all faiths teach that financial contributions to the church are obligatory, nor do all adherents of faiths that have such teachings necessarily agree with or follow them, ${ }^{318}$ but it is reasonable to apply this policy to churches of all faiths in order to avoid the difficult task of distinguishing among them on this ground. And again, this is a policy, not constitutional, argument that both supports providing the charitable contribution for donations to churches and not taking away that benefit for violating fundamental public policy.

Moreover, the charitable contribution deduction is the government's way of fostering comity toward the church. Church members pay taxes, and the state leaves to the church its share through the charitable contribution deduction. The availability of the standard deduction as a way of effectuating the charitable contribution deduction does not undermine the philosophical basis upon which the deduction is offered because the standard deduction exists not to undermine the principles underlying itemized deductions but is instead a practical choice by Congress to simplify tax collection. ${ }^{319}$ By allowing church members to reduce their taxable income based on money they donate to churches, through either an itemized or standard deduction, the government not only acknowledges the autonomy of churches to manage their own money, but it also recognizes that the sphere that is "the church" is composed of individuals whose allegiance to the church cannot be cause for their adverse treatment under the principle of noninterference. Without the charitable contribution deduction, church members who give to their churches would per se owe a higher percentage of their postcontribution income in taxes and would thus have less disposable

with the charitable contribution deduction addressed here, the "tax base" refers to a private citizen's taxable income.

318. See David W. Case, Comment, Resolving the Conflict Between Chapter 13 of the Bankruptcy Code and the Free Exercise Clause - In re Green: A Step in the Wrong Direction, 57 Miss. L.J. 163, 164-65 (1987).

319. Steve R. Johnson, Administrability-Based Tax Simplification, 4 NEV. L.J. 573, 58486 (2004). 
income than would those who do not donate to churches. Having the "right and duty" to "compel mutual regard for the boundarylines of [different spheres]" and to "defend individuals ... against the abuse of power," the state cannot rightfully allow such adverse treatment between those who donate to churches and those who do not. $^{320}$

Furthermore, from an empirical standpoint, seventy-four percent of churches' revenue comes from charitable contributions. ${ }^{321}$ Economists predict that without the charitable contribution deduction, charitable gifts to churches would decrease by just over twenty-two percent, ${ }^{322}$ which would have a major impact given that in 2017 American churches received over $\$ 127.37$ billion in contributions. ${ }^{323}$ This figure likely is lower now because of recent tax law changes that will cause a substantial decrease in the proportion of households that itemize their deductions. ${ }^{324}$ Nevertheless, the loss of eligibility to receive tax deductible contributions almost certainly would still have a significant negative effect on giving to churches since many high-income households can still take advantage of this deduction. ${ }^{325}$ Therefore, the United States as the sphere of spheres has the power, via its taxation policies, to substantially affect churches' budgets. To abide by the principle of noninterference, and against the reality that donations to churches have been tax deductible for generations, the government should refrain from enacting policies that reduce the amount of funds available to churches. Eradicating the charitable contribution deduction would have this effect, a clear reduction of the degree of autonomy a

320. KUYPER, supra note 221, at 124-25.

321. Evelyn Brody \& Joseph J. Cordes, Tax Treatment of Nonprofit Organizations: $A$ Two-Edged Sword?, in NONPROFITS \& GOVERNMENT: COlLABORATION \& CONFLICT 133, 137 (Elizabeth T. Boris \& C. Eugene Steuerle eds., 2011).

322. Id at 138 .

323. Thad S. Austin et al., Giving to Religion, in GIVING USA 2018: THE ANNUAL REPORT ON PHILANTHROPY FOR THE YEAR 2017, at 173 (2017).

324. See TAX POL'Y CTR., What are itemized deductions and who claims them?, https://www.taxpolicycenter.org/briefing-book/what-are-itemized-deductions-andwho-claims-them [https://perma.cc/Z8QD-R3A7].

325. Id. 
church exercises over its resources. Consequently, if a church taught that its members ought not pay taxes to the government, the church itself would cease to abide by the principle of noninterference. Fair treatment among spheres-and especially fairness between the state and churches - runs in both directions.

\section{B. First Amendment Institutions}

While the concept of sphere sovereignty provides a philosophical basis for the proposed soft sovereignty approach in applying Bob Jones University to churches, the First Amendment provides a legal basis. About twenty years ago, dissatisfaction with the rules and categories of First Amendment law gave rise to what has been called the "institutional turn." ${ }^{326}$ In the "pre-legal world," individuals are not the only actors. Activities, specifically those which would otherwise be protected by the First Amendment, "happen[] ... through and by institutions." ${ }^{\prime 27}$ This real-world observation inspired a fresh approach to First Amendment issues, one that contends that institutions are morally relevant actors for the "definitions and distinctions drawn in First Amendment doctrine." ${ }^{\prime 328}$ That is, under this First Amendment institution theory, the substantive guarantees of the First Amendment protect not only individuals but groups of organized individuals - namely, institutions. ${ }^{329}$

To determine what constitutes a First Amendment institution, Professor Horwitz proposes that two elements be satisfied: that the institution plays a central role in public discourse, and possesses self-regulatory norms and practices. ${ }^{330}$ The former is not so broad as to encompass any institution that contributes to public discourse but is limited to those institutions that are "fundamental" to the "infrastructure" of public discourse. ${ }^{331}$ Thus, while other types of

326. HORWITZ, supra note 258, at 74-75; Richard W. Garnett, Do Churches Matter? Towards an Institutional Understanding of the Religion Clauses, 53 VILL. L. REV. 273, 276-84 (2008).

327. Garnett, supra note 326, at 277.

328. HORWITZ, supra note 258 , at 74-75

329. Id.

330. Id. at 81 .

331. Id. at 244 . 
legal entities participate in public discourse, they are not essential to its infrastructure in the way that newspapers, libraries, and universities are ${ }^{332}$ Additionally, institutions that are self-regulatingthose that "operate according to a rich set of norms, practices, and rules" - satisfy the second prong of the First Amendment institution definition and ought to be legally recognized as such. ${ }^{333}$ This two-prong definition serves as a helpful guide for characterizing institutional actors for First Amendment purposes.

The above discussion on soft sovereignty supplies the theoretical basis for affording First Amendment institutions some sovereign control. ${ }^{334}$ In short, the government ought to respect the autonomy inherent to First Amendment institutions, as they are sovereign within their own spheres. This soft sovereignty approach is not, as was shown above, without its limits, and the government may still restrict the conduct of such institutions, at least in some respects. 335 The rights guaranteed by the First Amendment remain, however, necessary protections against an over-intrusive state.

Building upon this institutional framework, many commentators have argued that churches should be recognized as First Amendment institutions. ${ }^{336}$ Applying Professor Horwitz's two-part test renders churches First Amendment institutions, for they "are surely well-established, self-governing institutions with a longstanding infrastructural role in public discourse and a unique

\section{See id.}

333. Id. at 86 .

334. HORWITZ, supra note 258 , at 93-96.

335. See infra Part V.C.

336. See, e.g., HORWITZ, supra note 258, at 174-93; Garnett, supra note 326; Richard W. Garnett, The Freedom of the Church: (Toward) an Exposition, Translation, and Defense, in THE RISE OF CORPORATE RELIGIOUS LIBERTY 39, 45 (Micah Schwartzman et al. eds., 2016); Douglas Laycock, Towards a General Theory of the Religion Clauses: The Case of Church Labor Relations and the Right to Church Autonomy, 81 COLUM. L. REV. 1373, 1373 (1981); Victor E. Schwartz \& Christopher E. Appel, The Church Autonomy Doctrine: Where Tort Law Should Step Aside, 80 U. CIN. L. REV. 431, 460-61 (2011); cf. Steven D. Smith, Freedom of Religion or Freedom of the Church? (Univ. of San Diego Legal Stud. Rsch. Paper Series, Paper No. 11-061, 2011) (arguing that the First Amendment Religion Clauses are about collective religious practice), https://papers.ssrn.com/sol3/papers.cfm?abstract_id=1911412 [https://perma.cc/ZF6V-P4EN]. 
set of contributions to make to it." ${ }^{\prime 37}$ Moreover, the constitutional text supports an institutional conception of churches under the First Amendment. As Professor Richard Garnett argues, "An appreciation for the rights and independence of religious institutions, and an account of the implications of these rights for the financial, regulatory, cooperative and other relations between religious and governmental institutions, is a crucial component of any attractive account of the Religion Clauses." ${ }^{338}$

While the Supreme Court has not explicitly applied the institutional approach to churches in First Amendment challenges relating to taxes, it has assumed that religious institutions (and churches specifically) enjoy First Amendment protections. ${ }^{339}$ In Bob Jones University itself, the Court assumed that Bob Jones University and Goldsboro Christian Schools-both religious schools-were protected by the Free Exercise Clause. ${ }^{340}$ It ultimately concluded that the government's compelling interest in eradicating racial discrimination in education outweighed the religious schools' free exercise rights. ${ }^{341}$ But it nonetheless assumed that the First Amendment applied to the religious schools as such. ${ }^{342}$ And in church property dispute cases, the Court has unambiguously recognized the First Amendment rights of churches. ${ }^{343}$ The leap from these precedents to affording First Amendment protections to churches in the tax context-a subset of religious organizations - is a small one at best. The next Part explores why this is the case.

337. HORWTTZ, supra note 258, at 176; see also id. at 244 ("Certain entities-churches, newspapers, libraries, and so on-are clearly vital parts of that infrastructure [of public discourse].").

338. Garnett, supra note 326, at 293.

339. See infra note 343.

340. Bob Jones Univ. v. United States, 461 U.S. 574, 603 (1983).

341. Id. at 604 .

342. See also Our Lady of Guadalupe Sch. v. Morrissey-Berru, 140 S. Ct. 2049, 2055 (2020) (applying the Religion Clauses to a religious school); Hosanna-Tabor Evangelical Lutheran Church \& Sch. v. EEOC, 565 U.S. 171, 188-92 (2012) (same).

343. See, e.g., Jones v. Wolf, 443 U.S. 595, 605 (1979); Presbyterian Church v. Mary Elizabeth Blue Hull Mem'1 Presbyterian Church, 393 U.S. 440, 448-52 (1969); Kedroff v. Saint Nicholas Cathedral, 344 U.S. 94, 120-21 (1952). 


\section{Churches Distinguished}

Theoretically, the soft sovereignty theory and First Amendment institution framework could justify the special tax treatment of many non-religious groups. In Bob Jones University, the Supreme Court applied the contrary-to-fundamental-public-policy doctrine to non-church religious institutions over their First Amendment objections. Because we accept Bob Jones University as a given for purposes of this Article, it is necessary to determine whether churches can and should be distinguished from non-churches when it comes to applying this doctrine. This Part argues that defining what constitutes a "church" is philosophically possible and is legally both possible and necessary.

1. Philosophical Basis for Distinguishing Churches

Religious skeptics-Professors Schragger and Schwartzman among them-argue that the soft sovereignty approach to churchstate relations proves too much, that the sphere sovereignty justification covers not only churches but could logically be extended to encompass all social spheres, including religious schools or hospitals. ${ }^{344}$ Moreover, why should the neighborhood fraternal organization or local small business not enjoy the same tax benefits that churches do given the sphere sovereignty framework? And further, if religious institutions can be distinguished from secular groups, is it possible to further delineate between churches and other kinds of religious organizations such as religious schools and hospitals? Their main contention lies with the first question; once churches can be distinguished from secular groups in theory, the law becomes the forum for the finer line-drawing required to answer the second question. ${ }^{345}$

Professors Schragger and Schwartzman's objection does not take up, as others have, the debate over whether religion is an inherent 
good, nor do they attempt to empirically weigh the (secularly perceived) social good against the (secularly perceived) social harm that churches promulgate. ${ }^{346}$ Instead, they phrase and reject the sphere-theorist's claim as follows: "The religious institutionalist ... has to claim not only that religion is good but that organized religion facilitates, promotes, or is constitutive of that good."347 Stated another way, the sphere-theorist's "instrumental claim ... asserts that churches provide non-theologically-based benefits to society. But this raises the question of whether churches do so uniquely." 348 While we have slight reservations about the characterization of what exactly sphere-theorists must prove, we nonetheless engage in the debate as so framed.

In support of their argument, Professors Schragger and Schwartzman slightly mischaracterize Kuyper's theory. They note that Kuyper taught that sovereign spheres included "the family, the business, science, art and so forth." ${ }^{349}$ But that litany does not preclude a distinct conception of the church-as-sphere; indeed, it is entirely silent on "the Church." ${ }^{350}$ Kuyper scholar Professor Nicholas Wolterstorff assures us that it is "unmistakably clear that [Kuyper] regarded the church as fundamentally unique and regarded its autonomy under God as more fundamental than that of any other institution." 351 A cursory glance at the presentment of his sphere theory shows that Kuyper was careful to maintain distinctions between the State, Society, and the Church. ${ }^{352}$

Kuyper's main, albeit implicit, distinguishing factor is that churches are necessarily rooted in religious truths, whereas nonreligious groups are not. ${ }^{353}$ Churches, then, are social spheres that adhere to and practice religion, and non-churches are social spheres

347. Id. at 949 (emphasis omitted).

348. Id. at 953 .

349. Id. at 948 n.122 (citing KUYPER, supra note 221, at 90).

350. See id. at 948-49.

351. Wolterstorff, supra note 219 , at 116.

352. See KUYPER, supra note 221, at 99, 127.

353. See id. at 128-30. 
that do not adhere to nor practice religion. ${ }^{354}$ Professors Schragger and Schwartzman do not look at the specific beliefs held by churches or any social institution as a basis for distinguishing among them, and they accordingly make two errors in not crediting "religion" as a distinctive quality of churches. First, they assume that churches justify their institutional autonomy on conscience or associational rights-as opposed to collective doctrinal adherence-in setting the parameters of the church's sphere. Second, they rely upon that assumption to group churches together with other social institutions. But religious sphere theorists reject their first assumption in favor of a church uniqueness based on "religiosity." If religion is unique to churches, and by all accounts it is, then Professors Schragger and Schwartzman's conclusion that churches are indistinguishable from secular spheres fails.

Distinguishing churches from other social spheres on the basis of religion is, however, only half the battle for the religious sphere theorist. The question still remains: Why does religion deserve special treatment? That is, even if churches are distinguishable from secular spheres, what about the nature of religion requires that churches receive favors from the state? ${ }^{355}$ The secularly perceived benefits of a religious society are plentiful ${ }^{136}$ but contested. ${ }^{357}$ In any matter, the intangible benefits are ultimately what tip the scale in favor of a governmental structure that recognizes the importance of preserving a religious populace.

While some would disagree, we would argue that religion as a whole, albeit in its best form and in ways that vary among faiths, is a conduit for social and moral good. So promulgated by churches,

355. This is the argument Professors Schragger and Schwartzman ultimately raise. See supra notes $347-48$ and accompanying text.

356. See Schragger \& Schwartzman, supra note 272, at 950 n.131.

357. See id. at 950 n. 130 . 
religions teach their adherents principles, in both form and substance, that are unique among other social spheres. ${ }^{358}$ Religion promotes respect for authority, a necessary feature of a sustainable democracy. ${ }^{359}$ It fosters concern for one's community and for the poor, and as one commentator put it, "Exclusive concern for self-interest is the very definition of the corruption of republican virtue." ${ }^{360} \mathrm{Re}-$ ligion occupies a unique space because "[c]hurches, as communities of spiritual discernment and moral reflection, can begin conversations about the common good within their own communities and then reach out to include other persons and institutions." 361 Religious groups make the pursuit of supernatural and moral truths their primary activity in a way that secular organizations simply do not. And in a society in which rights are perceived as God-given, ${ }^{362}$ religion plays a vital role in promoting the dignity of the human person-a dignity that the law endeavors to recognize and protect. ${ }^{363}$

\section{Legal Basis for Distinguishing Churches}

But regardless of whether one accepts this philosophical argument, is there a legal basis for distinguishing churches from other types of religious organizations? The Court itself suggested there may be in carefully setting to the side whether its holding in $B o b$

358. See e.g., PONTIFICAL COUNCIL FOR JUSTICE AND PEACE, COMPENDIUM OF THE SOCIAL DOCTRINE OF THE CHURCH (2004), http://www.vatican.va/roman_curia/pontifical_councils/justpeace/documents/rc_pc_justpeace_doc_20060526_compendio-dottsoc_en.html [https://perma.cc/KQTW-EDYF].

359. See RichaRd JOHN NeUHAUS, THE NAKED PUbliC SQUARE: REligion AND DEMOCRACY IN AMERICA 82-84 (1984).

360. Robert N. Bellah, Religion and Legitimation in the American Republic, $\operatorname{SOC}^{\prime} \mathrm{Y}$, May/June 1978, at 16, 20.

361. BRIAN STILTNER, RELIGION AND THE COMMON GOOD: CATHOLIC CONTRIBUTIONS TO BUILDING COMMUNITY IN A LIBERAL SOCIETY 124 (1999).

362. See THE DECLARATION OF INDEPENDENCE para. 2 (U.S. 1776) ("We hold these truths to be self-evident, that all men are created equal, that they are endowed by their Creator with certain unalienable Rights, that among these are Life, Liberty and the pursuit of Happiness." (emphasis added)).

363. See id. ("That to secure these rights, Governments are instituted among Men, deriving their just powers from the consent of the governed ...."). 
Jones University applied to "churches or other purely religious institutions." ${ }^{364}$ And while the Court in some decisions has extended religious liberty protections to non-church religious organizationsfor example, the ministerial exception cases both involved religious schools ${ }^{365}$-in others it appears to have limited those protections to churches ${ }^{366}$ Finally, when a non-church religious organization provides secular services or goods such as education or health care in a manner that is contrary to fundamental public policy, the government's interest in not supporting that organization through tax benefits is significantly stronger than in the church context. This is because, as the IRS has noted, provision of such services in a manner strongly disfavored by the government can, for example in the case of racial discrimination, "reasonably be expected to aggravate the disparity in the educational, economic, or social levels of [a racial] group when compared with society as a whole," ${ }^{\prime \prime 67}$ while a typical church discriminating with respect to employment, religious services, or membership will likely not have such an effect.

Therefore, even if a religious or sphere sovereignty skeptic adheres to the conscience-based conception of church autonomy, rejects the idea of the church as a First Amendment institution, or finds the above-proffered arguments for the distinctive treatment of churches altogether unconvincing, the law has recognized that churches can be distinguished and that churches, as religious organizations, ought to receive special treatment under the First Amendment. This observation does not dismiss the justifications

364. Bob Jones Univ. v. United States, 461 U.S. 574, 604 n.29 (1983).

365. Our Lady of Guadalupe Sch. v. Morrissey-Berru, 140 S. Ct. 2049, 2055 (2020); Hosanna-Tabor Evangelical Lutheran Church \& Sch. v. EEOC, 565 U.S. 171, 174 (2012).

366. See, e.g., Jones v. Wolf, 443 U.S. 595, 602 (1979) (affirming the First Amendment limitations on the role of civil courts to resolve church property disputes); Kedroff $v$. St. Nicholas Cathedral, 344 U.S. 94, 116 (1952) (identifying churches as having a particular freedom from state interference as a matter of religious liberty); Watson v. Jones, 80 U.S. 679, 728-29 (1871) (recognizing that decisions of church bodies are not reviewable by civil courts when based on internal church law); see also Ira Mark Ellman, Driven from the Tribunal: Judicial Resolution of Internal Church Disputes, 69 CALIF. L. REV. 1378, 1403 (1981); Ira C. Lupu \& Robert Tuttle, The Distinctive Place of Religious Entities in Our Constitutional Order, 47 VILL. L. REV. 37, 57-58 (2002).

367. I.R.S. Tech. Adv. Mem. 89-10-001 (Mar. 10, 1989); see supra note 86. 
offered above, it merely acknowledges that the law recognizes the uniqueness of churches, even if the underlying rationale for doing so has not been systematically and consistently explained. In other words, the American system has accepted the distinct space that churches occupy given the First Amendment's Religion Clauses, which themselves single out religion from other social spheres. ${ }^{368}$ As a practical matter then, we consider some instances in which courts have distinguished churches from non-churches so as to inform the line-drawing necessary to advance our position that $B o b$ Jones University should apply in a more limited fashion to churches. As noted earlier, the Supreme Court was careful to reserve the question of how the reasoning of Bob Jones University would apply to "churches or other purely religious institutions." 369 While its basis for doing so could reasonably be viewed as the fact that the public policy at issue related to education and so only applied to schools, there is another basis for distinguishing churches (and perhaps "other purely religious institutions," whatever exactly that means) from religious schools, hospitals, and other types of entities. That basis is the same one that underlies the ministerial exception with respect to the employment of religious leaders (albeit an exception the Court has extended beyond churches), ${ }^{370}$ the limited role of civil courts in resolving church property disputes, ${ }^{371}$ and the autonomy or soft sovereignty justification for the tax benefits generally enjoyed by churches ${ }^{372}$ - that the internal affairs of churches should generally not be subject to government interference because of both free exercise and entanglement concerns under the First Amendment.

In addition to the theoretical factors by which to distinguish churches for tax benefit purposes, the Constitution itself offers some distinguishing characteristics unique to the church setting.

368. See generally Richard W. Garnett, Religion and Group Rights: Are Churches (Just) Like the Boy Scouts?, 22 ST. JOHN'S J. LEGAL COMMENT. 515 (2007); Lupu \& Tuttle, supra note 366 .

369. Bob Jones Univ. v. United States, 461 U.S. 594, 604 n.29 (1983).

370. See Schragger \& Schwartzman, supra note 272, at 975.

371. See supra note 366.

372. See supra Part III.C.3. 
For example, while the Supreme Court accepted the constitutionally based ministerial exception in the context of a religious school, its reasoning applies even more strongly to churches. The Court designed the exception to prevent "government interference with an internal church decision that affects the faith and mission of the church itself." 373 The Court thus distinguished laws that incidentally burden outward expressions of religious conduct, such as the ban on the ingestion of peyote that the Court upheld even as applied to sacramental use in Employment Division v. Smith. ${ }^{374}$ While the ministerial exception cases are of course limited to the employment context, the reasoning in those cases mirrors that in cases involving internal church decisions that affect the faith and mission of the church itself, such as the church property disputes for which the Court has prohibited civil court involvement if they involve church law or ecclesiastical disputes. ${ }^{375}$ Such decisions would include, for example, those who may participate in religious activities and in what role. ${ }^{376}$ The soft sovereignty justification applies similarly to the tax context. If taxation would significantly interfere with the internal affairs of a church, then this respect for soft sovereignty should prevent such taxation. The key questions in both contexts are what falls within a church's internal affairs and what limits may be drawn.

The legal basis for the soft sovereignty justification is therefore the First Amendment. In requiring churches to conform their internal affairs to fundamental public policy when doing so is contrary to their religious beliefs, taxing churches for failure to comply with such policy substantially burdens free exercise of religion and invites substantial entanglement, and so is not permissible constitutionally absent a compelling governmental reason to do so. If a church engages in illegal activity, especially criminal activity, then

373. Hosanna-Tabor Evangelical Lutheran Church \& Sch. v. EEOC, 565 U.S. 171, 190 (2012).

374. Id.

375. See supra note 366.

376. See Mikochik, supra note 95, at 205 (freedom of expressive association protected by the First Amendment protects those "who could join in liturgy" even if, under Employment Division v. Smith, it does not encompass "what that liturgy could include"). 
that would generally provide such a reason, but non-illegal activity that conflicts with fundamental public policy generally does not.

\section{Defining "Church"}

This Article thus far argues that employing a soft sovereignty interpretation of Bob Jones University applied to churches is appropriate on philosophical and legal grounds and leads to a more limited application of that decision to churches than to charities. But what exactly is a "church"? Both Kuyper and the Supreme Court hesitate to allow the government to decide what constitutes a church. Kuyper posits that it is the church's "privilege, and not that of the State, to determine her own characteristics as the true Church, and to proclaim her own confession, as the confession of the truth." ${ }^{377}$ And the Court has echoed this view, steering clear of deciding cases on the basis of "the faith and mission of the church itself." ${ }^{378}$ But the church, as one social sphere among many, albeit a privileged one given the First Amendment, is not free to avoid all interactions with the government, and the Court ought not balk at deciding difficult First Amendment questions. For purposes of applying the fundamental public policy doctrine as we frame it, defining what exactly constitutes a church becomes a necessary line-drawing problem with which the courts must engage.

Which organizations should qualify as churches in the tax benefit context must be meaningfully limited. The existing IRS multi-factor test is difficult to apply and may lead to organizations that do not appear to be a church under most definitions being recognized as such for federal tax purposes. ${ }^{379}$ Indeed, commentators are increasingly concerned that the definition is already being stretched beyond recognition. ${ }^{380}$ Some courts are moving toward a test that considers many relevant factors but gives greatest weight to a 
congregational approach. ${ }^{381}$ Such an approach requires the regular, in-person gathering of individuals to engage in worship and other communal religious activities and appears to be better fit for what constitutionally should be viewed as a church and therefore eligible for this approach. ${ }^{382}$

The congregational approach has acquired acceptance among courts $^{383}$ and commentators, ${ }^{384}$ perhaps because it is an easily administrable, objective test and is arguably consistent with the text and history of the Religion Clauses. Narrow definitions, like the congregational approach, ensure that our proposed application of Bob Jones University to churches does not encompass a larger category of tax-exempt organizations than is necessary, desirable, or constitutionally required. But whatever definition is ultimately adopted, if a categorical definition is adopted at all, it must account for the basic distinction that the congregational approach captures well: churches are a subset of religious organizations, which are themselves a subset of Section 501(c)(3) nonprofit organizations.

To the extent that a narrow, court-made definition of church would exclude some entities that would otherwise qualify as a

hildt Moore, Comment, Religious Tax Exemption and the "Charitable Scrutiny" Test, 15 REGENT U. L. REV. 295, 307 (2003); Sarah Pullman Bailey, Major evangelical nonprofits are trying a new strategy with the IRS that allows them to hide their salaries, WASH. POST, Jan. $17,2020$.

381. See cases cited infra note 383 .

382. Transitory crises that make in-person services impossible-like pandemicswould not undermine an institution's legal status as a church, so long as it intends to resume in-person gatherings as soon as the transitory crisis ends. See Zachary B. Pohlman, "Churches" in a Time of Coronavirus, CANOPY FORUM (Oct. 2, 2020), https://canopyforum.org/2020/10/02/churches-in-a-time-of-coronavirus/ [https://perma.cc/S6]2KKTC].

383. See, e.g., Found. of Hum. Understanding v. United States, 614 F.3d 1383, 1391 (Fed. Cir. 2010); Church of Eternal Life \& Liberty, Inc. v. Comm'r, 86 T.C. 916, 924 (1986); Church of Visible Intelligence That Governs the Universe v. United States, $4 \mathrm{Cl}$. Ct. 55, 65 (1983).

384. See, e.g., Mirkay, supra note 106, at 740; Jacob E. Dean, "Do You Have That New Church App for Your iPhone?": Making the Case for A Clearer and Broader Definition of Church Under the Internal Revenue Code, 46 CREIGHTON L. REV. 173, 202 (2013); Wendy Gerzog Shaller, Churches and Their Enviable Tax Status, 51 U. PITT. L. REV. 345, 351-52 (1990). 
church under the IRS multi-factor test, there is no legal inconsistency. Churches, under the Bob Jones University framework, are a constitutional class, not a statutory or regulatory carve out. The IRS is, of course, free to exceed the constitutional floor in affording tax benefits to more groups than the Constitution requires. The IRS could not, however, exclude groups that would otherwise qualify as a church under a constitutional definition.

\section{REVISITING CHURCHES AND BOB JONES UNIVERSITY}

There are at least three ways to approach the application of $B o b$ Jones University to churches today. One way would be to take the contrary-to-fundamental-public-policy doctrine as stated in that case and assume it applies with equal force to religious organizations of all types, including churches. This is the approach that the IRS takes ${ }^{385}$ and was the approach we took in Part II. This approach led us to identify at least two areas of current conflict-sex discrimination, particularly in employment, and sanctuary churcheswhere the tax benefits enjoyed by a significant number of churches could be at risk. We also identified at least two areas of likely future conflict, although opposition to the church practice does not yet rise to the level of a fundamental public policy, in the case of sexual orientation discrimination, and the practice appears rare, in the case of polygamy.

Another approach would be to limit Bob Jones University to its historical and factual context-both the decades-long battle against racial segregation in education and the broader civil rights movement. The question would then become whether any of the current or likely future conflicts involve a similar confluence of strong political and societal pressures. This approach essentially asks whether the public policy at issue in Bob Jones University is distinguishable from the ones identified in Part II even if some or all of the latter might be considered fundamental. For the reasons detailed previously, we reject this approach. ${ }^{386}$ 
A third approach would be to consider not whether the fundamental public policies identified are distinguishable from the policy at issue in Bob Jones University, but instead whether the institutions being discussed here-churches-are distinguishable from the institutions involved in that case. For the reasons discussed above, our conclusion is that this is the best approach for deciding how, if at all, Bob Jones University should apply to churches, subject to certain limitations detailed in this Part.

\section{A. Current Significant Conflicts}

\section{Sex Discrimination}

With respect to sex discrimination, whether in employment, membership, provision of goods or services related to religious activity, or teachings, any attempt by the government to remove tax benefits from a church for such behavior would significantly interfere with internal church decisions and affairs (assuming the discrimination is based on religious doctrine) because it would almost certainly closely relate to the faith and mission of the church. The contrary-to-fundamental-public-policy doctrine should therefore not extend to this situation due to the religious liberty protections provided by the First Amendment, subject to the limits discussed further below.

2. Protecting and Serving Undocumented Immigrants

Unlike sex discrimination, which occurs only within the "sphere" of the church, sanctuary churches present a more complicated situation. The sphere of authority inherent to churches collides with the government's sphere of authority, both theoretically and physically, when churches harbor undocumented immigrants who would otherwise be deported. Setting aside whether churches who provide sanctuary act illegally, ${ }^{387}$ the question becomes whether the 
IRS can revoke the tax benefits of churches for opposing the fundamental public policy of not interfering with legal deportations when churches provide sanctuary.

On the one hand, nothing is more private-and hence, more removed from potential state interference-than how a church conducts itself within its own four walls. If the sphere metaphor is to have any practical implications, it must at least mean that the state cannot physically intrude upon the sanctuary absent extraordinarily compelling reasons for doing so (such as to prevent criminal activity). On the other hand, part of the "good" that churches offer to society is fostering respect for authority and promoting democratic principles. ${ }^{388}$ Openly defying immigration law seems to cut against this justification for the special treatment of churches within society.

Consider the church whose religious doctrine necessitates safeguarding the undocumented immigrant. ${ }^{389}$ That church is faced with a mutually exclusive choice: obey Caesar or obey God. That is, comply with secular law (and fundamental public policy) but violate religious law by releasing the immigrant to law enforcement, thereby retaining secular tax benefits, or comply with religious law by harboring the immigrant, thereby forfeiting secular tax benefits. Were a church to face such an ultimatum, its freedom of religious expression would be seriously threatened. In fact, the sanctuary church situation presents a quintessential example of the respective

388. See supra notes 359-363 and accompanying text.

389. See Jonathan Zasloff, Sanctuary, Civil Disobedience, and Jewish Law 1 (UCLA Pub. Law \& Legal Theory Rsch. Paper no. 19-33, 2019), https://papers.ssm.com/sol3/papers.cfm?abstract_id=3460605 [https://perma.cc/WU3N-S7MX] (Jewish law requires synagogues to shelter asylum-seekers from immigration authorities under certain circumstances); U.S. CONFERENCE OF CATHOLIC BISHOPS, AD HOC COMMITTEE FOR RELIGIOUS LIBERTY, OUR FIRST, MOST CHERISHED LIBERTY: A STATEMENT ON RELIGIOUS LIBERTY 3 (2012) (challenging state laws prohibiting the "harboring" of undocumented immigrants as conflicting with certain religious obligations), https:/www.usccb.org/committees/religious-liberty/our-first-most-cherished-liberty [https://perma.cc/6RVH-Z74D]; Daniel Burke, The Evangelical Lutheran Church in America just became the country's first "sanctuary church body," CNN (Aug. 8, 2019), https://www.cnn.com/2019/08/08/us/lutheran-sanctuary-church/index.html [https://perma.cc/6C77-88V4]. 
authority that church and state have over their own populations. In this case, the coercive power of the state must yield to the soft sovereignty inherent to the church when its members practice their religion.

This outcome is bolstered in light of the sanctuary concept being historically and theologically tied into the concept of the church itself as a place of not only spiritual but physical shelter for those seeking safety. ${ }^{390}$ One aspect of the modern sanctuary movement is that churches provide their protection only to those willing to remain physically within the confines of an existing church building. ${ }^{391}$ It is this physical limitation that ultimately tips the scale in favor of churches. For undocumented immigrants, it sharply limits their freedom and activities, and for churches, it demonstrates the integration of the sanctuary concept with the existing church's faith and mission.

\section{B. Likely Future Significant Conflicts}

Part II also identified two issues that, while not currently governed by fundamental public policy, are likely to produce conflicts in the future-namely, sexual orientation discrimination and polygamy. The social, political, and legal trajectory of the first issue is such that opposition to discrimination on the basis of sexual orientation may very well become a fundamental public policy. As for the second issue, it is possible that a greater number of churches that support polygamy may seek tax-exempt status and so create a conflict with the IRS, which has already indicated it considers opposition to polygamy to be a fundamental public policy. Should either of these developments occur, and should the IRS invoke Bob Jones University to repeal the tax benefits of a church that acts contrary to said fundamental public policy, the framework we offer above provides a way for courts to uphold the important religious

390. See Rhonda Shapiro-Rieser, The Sanctuary Movement: A Brief History, CTR. FOR RELIGIOUS AND SPIRITUAL LIFE (Mar. 1, 2017), https://sophia.smith.edu/religious-spiritual-life/2017/03/01/sanctuary-movement-history/ [https://perma.cc/JF24-KED8].

391. See, e.g., Laurie Goodstein, Houses of Worship Poised to Serve as Trump-Era Immigrant Sanctuaries, N.Y. TMES, Dec. 27, 2016. 
interests at stake, while it also draws certain bright-line rules on just how far both churches and the state can encroach into the sphere of the other.

\section{Sexual Orientation Discrimination}

Solicitor General Verrilli's admission ${ }^{392}$ merely confirmed what appeared to be true: religious organizations that discriminate on the basis of sexual orientation are potentially susceptible to a $B o b$ Jones University challenge in light of Obergefell. And if the federal government comes to consistently oppose sexual-orientation-based discrimination such that it becomes fundamental public policy, ${ }^{393}$ how ought the IRS or reviewing courts determine whether to strip churches of their tax benefits for violating such policy? Churches could discriminate on the basis of sexual orientation in essentially two ways. They could (1) refuse to perform same-sex weddings or provide other religious services to persons with a certain sexual orientation; or (2) disallow those who have a certain sexual orientation or who engage in certain prohibited sexual conduct from assuming positions of church authority or to be members at all. While certainly related, the two instances of disparate treatment are distinct and must be analyzed separately given a contrary-to-fundamentalpublic-policy challenge.

First, some churches, pursuant to their religious doctrine, do not perform same-sex weddings. Applying the above framework, we

392. See supra note 11 and accompanying text.

393. The federal government is not yet uniform in opposing discrimination on the basis of sexual orientation. For example, while the Supreme Court recently held that Title VII of the Civil Rights Act of 1964 prohibits sexual orientation discrimination in employment, the executive branch opposed this result and members of Congress were split in their views. See Bostock v. Clayton Cty., 140 S. Ct. 1731 (2020), Brief for the United States as Amicus Curiae Supporting Affirmance in No. 17-1618 and Reversal in No. 17-1623, Bostock v. Clayton Cty., No. 17-1618 et al. (U.S. Aug. 23, 2019); Brief of Amici Curiae Members of Congress in Support of Employers, Bostock v. Clayton Cty., No. 17-1618 et al. (U.S. Aug. 23, 2019) (eight Senators and forty Representatives); Brief Of Members of Congress as Amici Curiae in Support of the Employees, Bostock v. Clayton Cty., No. 17-1618 et al. (U.S. July 3, 2019) (thirty-nine Senators and 114 Representatives). 
must consider whether performing weddings is an essentially internal practice of a church. That is, when a church performs a wedding, is that an intrinsically religious activity, or are weddings outside the scope of a church's fundamentally religious beliefs and practices? The question answers itself. Whether a church holds religious views regarding marriage can be defined only by the church itself. Where a church holds to specific religious teachings regarding marriage, the state cannot use its coercive power of taxation to encourage or pressure a church into violating its sincerely held religious beliefs. As the Supreme Court stated in Masterpiece Cakeshop, "When it comes to weddings, it can be assumed that a member of the clergy who objects to gay marriage on moral and religious grounds could not be compelled to perform the ceremony without denial of his or her right to the free exercise of religion." 394 While churches are not immune from all government interference under this approach, ${ }^{395}$ one obvious implication of the soft sovereignty justification is that a church must retain the autonomy to decide which religious ceremonies it conducts and how those ceremonies are conducted, weddings included. If a church is unwilling to perform same-sex marriages, no act of the state-be it through revocation of tax benefits or otherwise-can compel a church to do so. Such a coercive act would cause unnecessary entanglement by the state in the internal affairs of churches by directly influencing their liturgical practices and would potentially raise serious First Amendment problems regarding a church's right to free exercise of religion.

The state's potential interference with liturgy in the marriage context is different than banning the use of peyote in religious ceremonies at issue in Employment Division v. Smith. ${ }^{396}$ Smith involved illegal drug use. ${ }^{397}$ Refusing to perform same-sex marriages is not illegal but is rather contrary only to (potential) fundamental public policy. Moreover, in Smith, the religious observers were prohibited 
from using peyote, but churches opposing same-sex marriage would be compelled to perform an act contrary to a sincerely held belief. When it comes to distinguishing inaction from action, requiring the latter by law implicates a much greater liberty interest. Additionally, Hosanna-Tabor confirms that "Smith involved government regulation of only outward physical acts. [Discrimination in hiring ministers], in contrast, concerns government interference with an internal church decision that affects the faith and mission of the church itself." ${ }^{398}$ Surely weddings, which are liturgical acts that affect the faith and mission of a church, should be afforded this same protection. Thus, while the soft sovereignty approach necessitates this result, current legal doctrine likewise supports this outcome.

Moreover, Obergefell itself, which at least implicitly predicted that same-sex marriage would become widely accepted, ${ }^{399}$ recognized that:

$[R]$ eligions, and those who adhere to religious doctrines, may continue to advocate with utmost, sincere conviction that, by divine precepts, same-sex marriage should not be condoned. The First Amendment ensures that religious organizations and persons are given proper protection as they seek to teach the principles that are so fulfilling and so central to their lives and faiths, and to their own deep aspirations to continue the family structure they have long revered. 400

Justice Kennedy envisioned that people on both sides of the samesex marriage discussion would continue to "engage those who disagree with their view in an open and searching debate." ${ }^{401} \mathrm{He}$ concluded the section on religion by noting that, while churches have

398. Hosanna-Tabor Evangelical Lutheran Church \& Sch. v. EEOC, 565 U.S. 171, 190 (2012).

399. Obergefell v. Hodges, 576 U.S. 644, 676 (2015) (noting the numerous legislative debates, referenda, and scholarly arguments that same-sex marriage should be recognized by the state).

400. Id. at 679-80.

401. Id. at 680 . 
the right to disagree with same-sex marriage, "[t]he Constitution ... does not permit the State to bar same-sex couples from marriage." ${ }^{402}$ Obergefell thus does not require churches to perform samesex marriages. If anything, it makes explicit the assumption that a church cannot legally be compelled to perform any marriages that are contrary to its sincerely held beliefs. ${ }^{403}$ Since Obergefell is arguably the case-or more broadly, the moment-that will have ushered in the acceptance of same-sex marriage as fundamental public policy, ${ }^{404}$ looking to Obergefell for extra guidance on churches' obligations under that policy makes sense. If the IRS does so, in accordance with the framework offered above, it must afford churches the autonomy not to perform same-sex marriages without the potential of forfeiting otherwise available tax benefits.

Second, some churches do not allow those who engage in samesex conduct or, less commonly, who have a same-sex orientation to obtain leadership positions within the church or possibly to be members or receive goods or services. ${ }^{405}$ Assuming again that fundamental public policy would someday be opposed to such discrimination, ought churches that disallow those who engage in same-sex conduct or who have specified sexual orientations from obtaining leadership roles, being members, or receiving goods and services have to forfeit their tax benefits under a Bob Jones University-based challenge? Again, the answer must be "no." In light of the soft sovereignty approach to church autonomy, churches should have complete authority over their internal hiring, membership, and goods and services provision practices-assuming al-

402. Id. (emphasis added)

403. See id.

404. See Pavan v. Smith, 137 S. Ct. 2075 (2017) (applying Obergefell to strike a state rule that did not allow both same-sex spouses to be listed as parents on their child's birth certificate).

405. See Julia Zauzmer \& Sarah Pulliam Bailey, United Methodist Church votes to maintain its opposition to same-sex marriage, gay clergy, WASH. POST (Feb. 26, 2019), https://www.washingtonpost.com/religion/2019/02/26/united-methodist-churchvotes-maintain-its-opposition-same-sex-marriage-gay-clergy/ [https://perma.cc/Y97UJNY8]; supra note 105 and accompanying text. 
ways that any discrimination is founded upon sincerely held religious beliefs. The First Amendment must allow churches to make these decisions without fear of retaliatory government action in the form of de facto taxation. Anything other than complete autonomy over these core church decisions would invite unnecessary and potentially unlawful entanglement by the state. ${ }^{406}$

\section{Polygamy}

Applying the above approach in the polygamy context renders a similar analysis but with notable distinctions. Unlike with same-sex marriage, in which the (assumed) fundamental public policy is in favor of same-sex marriage, the (IRS-assumed) fundamental public policy with regard to polygamy is strict opposition. This inverts the complications that arise in the same-sex marriage context. For one, instead of compelling churches to perform same-sex marriages by threatening revocation of tax benefits, the state, on the same threatened tax benefit revocation grounds, would prohibit a church from performing polygamous marriages. But do these distinctions make a difference? It is hard to find a principled reason that they should.

For churches that oppose same-sex marriage as a matter of religious doctrine, that doctrine is informed by views about human sexuality and what constitutes "marriage." 407 Both prongs that form the basis of such doctrine are based on "religious" assumptions. For churches that endorse polygamy, the basis of that belief rests on different doctrinal assumptions than those that oppose the practice, but churches that support polygamy nonetheless approach questions of sexuality and marriage in a religious manner. ${ }^{408}$ Since defining what constitutes "marriage" is religious, at least when defined by a church, the state has no authority to distinguish among

406. But see infra Part V.C. (limitations).

407. See, e.g., CATECHISM OF THE CATHOLIC CHURCH II 1601 (2016) ("The matrimonial covenant, by which a man and a woman establish between themselves a partnership of the whole of life, is by its nature ordered toward the good of the spouses and the procreation and education of offspring ....").

408. See, e.g., Plural Marriage and Families in Early Utah, THE CHURCH OF JESUS CHRIST OF LATTER-DAY SAINTS, https://www.churchofjesuschrist.org/topics/plural-marriageand-families-in-early-utah?lang=eng [https://perma.cc/SCZ9-UYRN]. 
and favor churches whose definitions of marriage comport with the state's preferred definition. Doing so would have the state exceed its sphere of authority by encroaching upon churches' sovereign spheres. Moreover, if the state could do so, then churches that oppose same-sex marriage would have no argument for retaining their autonomy, given their refusal to perform same-sex weddings. The state could simply reject the autonomy of such churches, compel compliance with the fundamental public policy, which is in favor of same-sex marriage, and force such churches to either lose their tax benefits or perform same-sex marriages. Assuming, then, that a church holds a sincere religious belief that endorses the practice of polygamy, the state-pursuant to the principle of noninterference and in respecting church autonomy - cannot interfere with that practice by revoking such a church's tax benefits.

But the state's noninterference need not extend so far as to endorse polygamy itself. In other words, just as the state cannot coerce a church into halting the performance of polygamous marriages, neither can a church that supports polygamy coerce the state into endorsing polygamous marriages. Thus, while the state cannot stop a church from performing a polygamous marriage, it does not have to legally recognize such marriages. ${ }^{409}$ The state need not contradict its own fundamental public policy - which (assuming arguendo) defines marriage as a union between two, and only two, consenting adults-by endorsing polygamous unions. Each institution is only sovereign, and thus autonomous, within its own sphere. That applies equally to churches as well to the state. In light of the view advanced in this Article, the state could not prohibit a church from performing a polygamous marriage within a religious context, but the state would not have to validate that union and act contrary to fundamental public policy by issuing marriage licenses that endorse polygamy. And if the practices of the church led to violation 
of state criminal statutes prohibiting bigamy, as the IRS found was the case with a church that promoted polygamy, ${ }^{410}$ then denial of tax-exempt status would be justified for the reasons detailed in the next Part.

\section{Limitations}

This approach has several limitations. First, as mentioned earlier it should only apply to the contrary-to-fundamental-public-policy doctrine and not the related but distinct illegality doctrine, because in our current legal system churches and their leaders are not fully separate and equal sovereigns who are above the law (or more accurately, not subject to the government's laws). Rather, the soft sovereignty approach, while recognizing church autonomy, is cognizant of the fact that churches are one of many societal spheres-the state as sphere of spheres chief among them. If churches were above the law, we would be in a world where the hard sovereignty approach to the application of tax and other laws to churches was still in place. The protections of the First Amendment do not go that far.

Therefore, if a church is found by the appropriate authority to have engaged in illegal behavior as a significant part of its activities, including with respect to sex discrimination or immigration laws, that would justify the loss of the tax benefits that churches otherwise enjoy. An extreme example of such a situation would be a church that engages in human sacrifice - that is, murder-but more realistic examples also exist, such as the church that was found to have engaged in the distribution of marijuana. ${ }^{411}$ Of course, in this situation the church and its leaders likely will be more concerned about the direct sanctions associated with that illegal behavior than the indirect tax consequences, as noted previously.

Second, and relatedly, there is the issue of whether the illegal behavior should be limited to criminal illegality or also extend to violations of civil laws. Given the breadth of civil laws at both the federal and state levels and the triviality of the activities they penalize 
in many instances, we believe only criminal activities should be able to form the basis for revocation of tax-exempt status for a church under the Bob Jones University decision. This appears to be the approach the IRS has usually taken, including with respect to applying the illegality doctrine to churches. ${ }^{412}$

Finally, for the reasons stated previously, this Article has accepted Bob Jones University as a given, and so has not questioned the Court's holding in the case that the First Amendment does not shield non-church religious organizations from the contrary-tofundamental-public-policy doctrine. In addition, we have noted that when non-church religious organizations provided secular services or goods in a manner that is contrary to fundamental public policy, the government has a stronger interest in denying them tax benefits than it does in the case of a typical church, although some commentators would reject this distinction. ${ }^{413}$ Accepting this limitation, if a church is engaged in secular education, health care, or similar activities the contrary-to-fundamental-public-policy doctrine would still apply. The previously discussed IRS decision to revoke the tax-exempt status of a legal entity that housed both a traditional church and a racially discriminatory school was therefore correct, especially since the church could avoid the loss of tax benefits by moving the school into a separate (taxable) legal entity. ${ }^{414}$

\section{CONCLUSION}

While rarely invoked, Bob Jones University remains good law and so provides a potential basis for revoking the tax benefits normally

412. See supra Part I.B.

413. See supra note 367 and accompanying text (supporting this distinction); Robert M. Cover, Foreword: Nomos and Narrative, 97 HARV. L. REv. 4, 66 (1983) (rejecting this distinction).

414. Indeed, this is the strategy that Bob Jones University used to obtain tax-exempt status under Section 501(c)(3) for its art museum. See Bob Jones Univ. Museum \& Art Gallery v. Comm'r, 71 T.C.M. (CCH) 3120 (1996); Victoria B. Bjorklund, Spinoffs: Bob Jones University Museum and Beyond: Evolving Techniques for Use of For-Profit Subsidiaries, Asset Protection, and Other Multiple-Entity Structures, ALI-ABA COURSE OF STUDY, Dec. 5, 1996. 
enjoyed by certain nonprofit organizations, as highlighted by the exchange during the Obergefell oral argument. Moreover, there are both current and foreseeable conflicts between the activities of some churches and likely fundamental public policies. Yet while the IRS has indicated it views the decision as fully applying to churches, the Supreme Court has never so held. Based on longstanding philosophical views of how churches and the state should interact and a more recent theory regarding how the First Amendment should govern such interactions, we conclude that $B o b$ Jones University should not apply with full force to churches. Instead, it should apply only if a church violates the illegality doctrine by engaging in significant criminal activities. But if instead a church's activities are only contrary to fundamental public policy, then the state should recognize a church's autonomy or soft sovereignty by providing the church with the tax benefits to which it is entitled. 